Agnieszka Wierzbicka-Olejniczak*

\title{
Komunikacja językowa i grzeczność w Internecie
}

\author{
Jezyk internetowy [...] jest w dużym stopniu odbiciem \\ jezzyka codziennej komunikacji i bez oparcia w tym \\ języku nie mógtby funkcjonować.
}

Grzenia 2006: 181

\section{Specyfika KOMUNIKaCJI W SIECI}

Internet, najdoskonalsze obecnie multimedium, łączy ze sobą rzesze ludzi (niezależnie od czasu, miejsca zamieszkania, wykonywanej pracy, narodowości czy statusu społecznego) i jest miejscem, w którym dzięki serwisom społecznościowym, poczcie elektronicznej, grupom dyskusyjnym, grom online, czatom czy udostępnianym na stronach WWW informacjom dochodzi do stałej komunikacji. Język używany w sieci kształtuje się w specyficznych okolicznościach i wyraźnie wyróżnia się z ogółu języków medialnych (zob. Grzenia 2006: 23). Dzieje się tak przede wszystkim dlatego, że użycie komputera i Internetu pociąga za sobą interakcję uczestników komunikacji, jaka nie była dotąd możliwa w innych - zarówno „starych”, jak i „nowych”- mediach. Zdeterminowane różnymi technologiami i narzędziami formy komunikacji (typ konwersacyjny, korespondencyjny i hipertekstowy) umożliwiają internautom porozumienie się - od równoczesnych (synchronicznych) pogawędek przez komunikatory, na czatach i podczas gier online, poprzez rozmowy (asynchroniczne) na forach, w korespondencji elektronicznej, aż po odbiór tekstów zamieszczanych na różnego typu stronach WWW. Dominującą cechą porozumiewania się w sieci jest (bez względu na wspomniane

"Dr Agnieszka Wierzbicka-Olejniczak - Uniwersytet Łódzki, Wydział Filologiczny, Katedra Współczesnego Języka Polskiego, al. Kościuszki 65, 90-514 Łódź. 
powyżej typy komunikacji) dialogowość. Role nadawcy i odbiorcy mogą się w Internecie dynamicznie zmieniać, co daje ogromne możliwości nawiązania i podtrzymania kontaktu. Łatwość, z jaką można porozumieć się z innymi użytkownikami sieci sprzyja spontaniczności, kolokwialności i często bardzo bezpośrednim zachowaniom językowym, co z reguły przejawia się w całkowitym skróceniu dystansu między rozmówcami oraz w mniej starannym (a nawet niestarannym) zapisie, dodatkowo wzbogaconym elementami graficznymi (np. emotikonami). Ze względu na pisany charakter komunikacji, wypowiedzi pojawiające się na czatach, w grupach dyskusyjnych, na forach, w portalach społecznościowych są odpowiednio usystematyzowane - kolejność, w jakiej ukazują się odbiorcom jest ściśle określona, niejako wymuszona przez technologię i wskazuje na hierarchiczny układ konwersacji (ostatnia wypowiedź ukazuje się albo na górze, albo na samym końcu prowadzonej rozmowy). Technologia używana do komunikacji powoduje także, iż komunikaty pojawiające się w Internecie mogą się dynamicznie zmieniać (choćby dzięki bieżącej aktualizacji), dowolnie przekształcać, mogą być rozbudowywane czy skracane, w zależności od potrzeb internautów. Należy jednak pamiętać, że mimo tych zmian nie mniej istotną cechą komunikacji w Internecie jest jej trwałość - dzięki różnorodnym i stale rozwijającym się technologiom zachowanie informacji nie stanowi żadnego problemu, podobnie jak jej udostępnienie.

Wskazane tu specyficzne właściwości pragmatycznojęzykowe komunikowania się za pośrednictwem komputerów i Internetu odróżniają tę formę porozumiewania od innych odmian języka polskiego i stanowią ciekawy przyczynek do głębszych analiz językoznawczych.

\section{Polszczyzna W internecie}

Internet, jako stosunkowo nowa przestrzeń masowej komunikacji międzyludzkiej, multimedium w pełni demokratyczne i niekontrolowane w żaden sformalizowany sposób, jest miejscem, gdzie język polski funkcjonuje w różnych odmianach. Gdy początkowo zaczęto używać Internetu (w Polsce był to koniec lat 80.), służył on przede wszystkim naukowcom do komunikacji oficjalnej. Z czasem, stając się medium powszechnym, dającym możliwość samodzielnego pisania każdemu aktywnemu użytkownikowi, upowszechnił codzienną komunikację na niebywałą dotąd skalę - skalę, jakiej nie dawało i nie daje do dziś żadne inne medium. Dzięki szybkiemu publikowaniu i upowszechnianiu swoich wypowiedzi każdy użytkownik 
sieci otrzymał możliwość swobodnego porozumiewania się z nieograniczoną liczbą odbiorców. Media sprzed ery Internetu nigdy nie dawały ludziom tak szerokiej perspektywy komunikacyjnej i nie umożliwiały tak wielowymiarowej interakcji - otwarcie na ogromną liczbę odbiorców spowodowało, że potoczna odmiana języka zagościła na stałe w Internecie, używana nie - jak dotychczas - jako odmiana mówiona, ale jako realizowana za pomocą pisma. Sposób ujmowania i zapisywania przez internautów własnych myśli zdeterminował przebieg porozumiewania się - w sieci do odbiorców dociera niemal wyłącznie słowo zapisane, wzbogacone dodatkowo o elementy graficzne, dźwiękowe, wideo itp. Niezwykle trafnie ujął to Gajda: „Wygląda na to, że tradycyjny paradygmat kultury opartej na dominacji druku ustępuje nowemu paradygmatowi z przewagą kodu audiowizualnego [...]. Internet, ustanawiając monitorowy byt tekstów, ikonizuje pismo - do odbiorcy dociera obraz pisma" $(2000,25)$. Pisanie w Internecie stało się więc wytwarzaniem komunikatu przeznaczonego do przeczytania, którego odbiorca zwraca w pierwszym rzędzie uwagę tylko na komunikat, za którym ukrywa się nieobecna osoba, a nie na samą osobę, jak ma to miejsce w bezpośredniej komunikacji (por. Labocha 2004, s. 5-10).

Masowość komunikacji internetowej i brak jakichkolwiek instytucji, które w sformalizowany sposób wpływałyby na formę i jakość porozumiewania się spowodowały, że polszczyzna potoczna rozprzestrzeniła się w sieci i zaczęła być dominującym wariantem języka, szczególnie w typie konwersatoryjnym i korespondencyjnym (portale społecznościowe, czaty, komunikatory internetowe, gry online). Można powiedzieć, że po części spełniła się przepowiednia pierwszych internautów: „Przyjdzie ta niewykształcona swołocz ze swoimi przeglądarkami WWW i pogrzebie to, co dotąd zdołał osiągnąć Internet: rzeczowość, klarowność, wreszcie ten ogólnie przestrzegany savoir-vivre!" (Chaciński 2003: 90). Oficjalność w internecie nie stanowi istotnej wartości dla znacznej części internautów, a wręcz jest przez nich ignorowana - nawet podczas tworzenia wypowiedzi, które takiego wariantu języka wymagają (np. w komunikacji urzędowej odbywającej się za pośrednictwem poczty elektronicznej). Łatwiej odnaleźć ją w języku funkcjonującym $\mathrm{w}$ sieci ( $\mathrm{tj} . \mathrm{w}$ tekstach tworzonych poza Internetem, a publikowanych $\mathrm{w}$ nim) niż w języku używanym w sieci (tj. w komunikatach powstających bezpośrednio $\mathrm{w}$ Internecie, $\mathrm{w}$ tekstach prymarnie internetowych) (zob. Grzenia 2006: 181).

Najczęściej dostrzegalnym objawem kolokwialności komunikacji internetowej wydaje się łamanie norm i reguł panujących w ogólnej polszczyźnie, szczególnie gdy chodzi o naruszanie normy ortograficznej i interpunkcyjnej (zob. ilustr. 1, 2). 


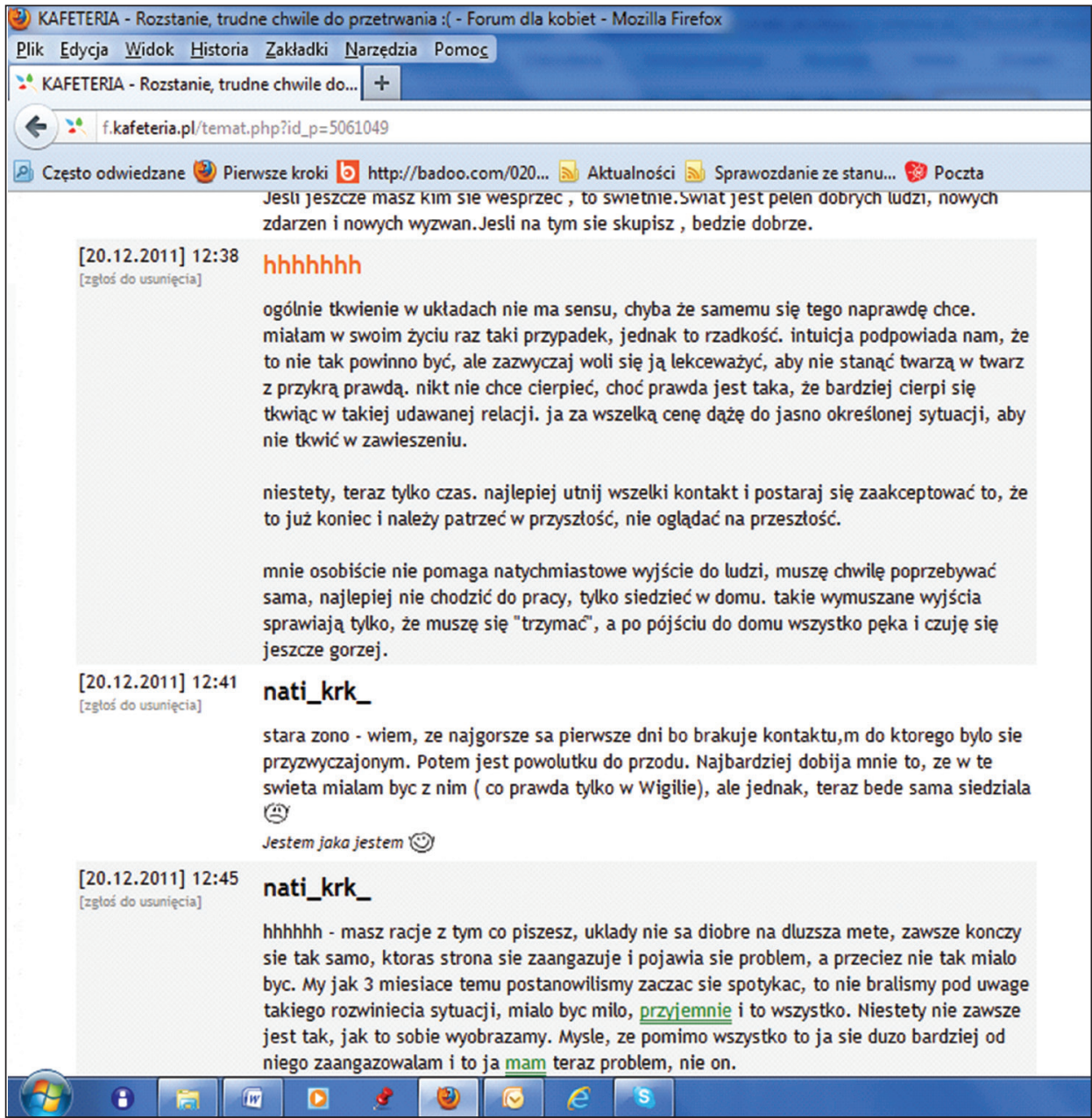

Ilustr. 1. Fragment rozmowy prowadzonej na forum

Źródło: strona internetowa www.kafeteria.pl/forum [dostęp: 2.02.2012]

Szczególnie wyraźnie zauważalny jest:

- brak wielkich liter przy zapisie nazw własnych, pierwszych wyrazów w zdaniu, np.:

ciekawe rysunki, te dwa ostatnie mam na myśli ; $\mathrm{d}$ hehe, te pierwsze 3 widać, że stare ;D masz ciekawy styl ; d a smok sofii ładny XD tylko ten łeb konia przypomina bardziej ; d (www.forumnasze.pl);

cobain zmarl sobie to fakt..bo byl normalnym czlowiekiem jak kazdy z nas ale muzyka nigdy nie umrze poki sa ludzie...poki sa ludzie ktorzy kochaja muzyke $: \dot{*}$ a wierze ze grunge bedzie kochany jeszcze i przez wnukow ..naszych prawnukow $(:))$ ) (http://forum.muzyka.pl); 
- brak polskich znaków diakrytycznych, np.:

Ja tez uwazam ze maja swoich, a kierowniczka wyglada na bardzo nie mila mialam okazje zamienic z nia 2 slowa, Bo Pytalam dlaczego nawet nikt sie nie konbtaktuje skoro sklada sie u nich cv?!Na to odpowiedz dostalam ze oni nie przetrzymuja dokumentow (http://chojnice24.pl/forum);

- zapis z błędami ortograficznymi, np.:

Fajny tekścik na końcu by tuitam $\because$ (http://forumzn.pl);

Dobre co $\because$ WIEC SZUKAJMY dalej kolezanki i koledzy bo ten ROSMANN niestoii otworem dla postronnych a dl;a swoich. Pozdrawiam Pania kierownik hehe $\ddot{\ddot{*}}$ (http://chojnice24.pl/forum);

strone mogl ci ktos shaczyc...ale dostep do ftp-a? (http://forum.joomla.pl).

Interpunkcja na polskojęzycznych stronach internetowych jest dwojaka - teksty są jej pozbawione (brakuje przede wszystkim znaków oddzielających, tj. przecinków, średników i kropek) albo używa się niestandardowo znaków interpunkcyjnych w funkcjach prozodycznych (wielokropki, pytajniki) czy emotywnych (wykrzykniki, pytajniki), najczęściej nadmiarowo, np. „nie eeee tam tylko oj tam oj tam ! ! ! ! ! ” (www.zakopaneforum.pl), ,i nie wariacie!!!!! ;P” (www.polchat.pl), „Mój wybór pada na........” (www.autovat. pl), „Już na wstępie byłem w lekkim szoku bo zamiast Happy w słuchawce usłyszałem Eko (???!!!?????), ale to pikuś akurat" (http://forum.gazeta.pl). Ponadto znaki interpunkcyjne znalazły w sieci nowe zastosowanie - stały się elementami tworzącymi emotikony: „[...] symboliczny ludzki grymas twarzy, obrócony o $90^{\circ} \mathrm{w}$ kierunku przeciwnym do wskazówek zegara, w licznych wariantach. Niektóre programy służące do komunikacji automatycznie zmieniają emotikony na ich graficzny odpowiednik"(Wikipedia, hasło: emotikon). Niekiedy dodawanie identycznych elementów interpunkcyjnych do istniejącego już emotikonu wskazuje na natężenie danego stanu emocjonalnego - i tak, znak oznaczający uśmiech :-) uzupełniony dwoma, trzema, czterema nawiasami zamykającymi ukazuje coraz większą radość:

$$
:-(\rightarrow:-)) \rightarrow(-))) \rightarrow(-)))) \rightarrow:-())))) \rightarrow(-())))) \text { ) }
$$

czy przymrużenie oka, np. „To był obrazek poglądowy pokazujący ramię dzia-

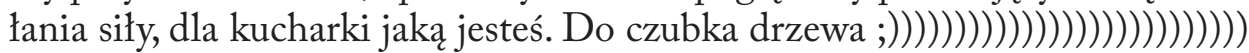
()$\left.\left.\left.\left.\left.\left.\left._{)}\right)()\right)()\right)()\right)\right)()\right)\right)$) Na tym odcinku moment siły jest równy ZERO, sznycelku" (http://forum.gazeta.pl).

Natomiast zastosowany kilkakrotnie nawias otwierający wskazuje na pogłębiający się smutek:

$$
:-(\rightarrow:-((\rightarrow):-(((\rightarrow:-)((() \rightarrow:-)((() \rightarrow:-)(()((
$$




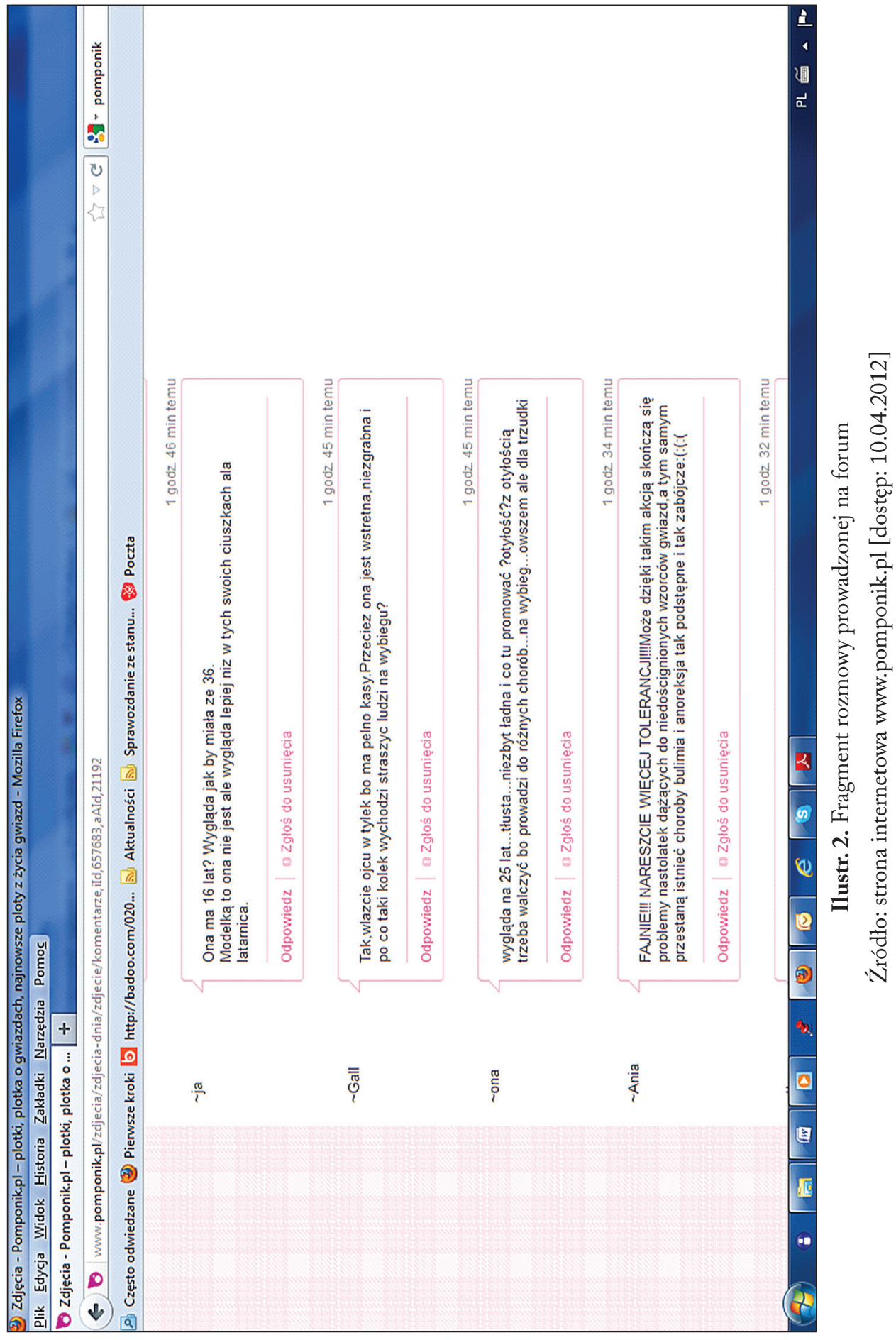




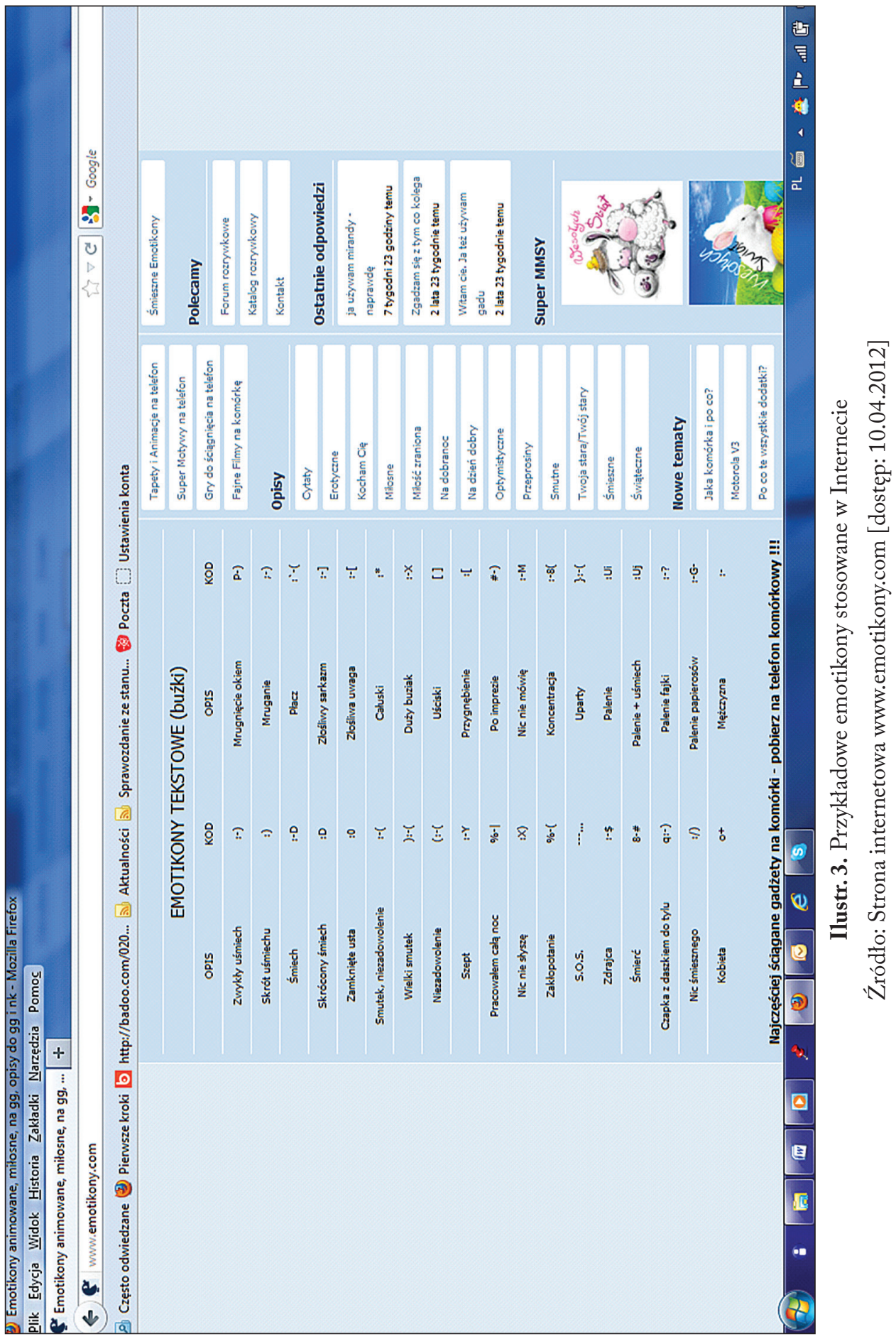


Interpunkcja, w nieznacznym stopniu rekompensując brak prozodii, dała podstawę do tworzenia symbolicznych znaków i stała się w sieci (oraz z czasem poza nią, w SMS-ach czy nawet krótkich notatkach stosowanych w codziennej komunikacji nieformalnej) oryginalnym sposobem manifestowania stanów emocjonalnych, wyrażania stosunku piszącego do treści, urozmaiceniem tekstu, żartem czy nawet twórczością (por. Grzenia 2006: 138) (zob. ilustr. 3).

Opisując specyfikę użycia emotikonów przez internautów, Grzenia (2006: 139-141) zwraca uwagę, że te symboliczne znaki stanowią zbiór hierarchiczny, w którym największą popularnością cieszą się uśmiechy :), :-), mrugnięcia okiem ;), ;-) czy obrazy smutku :(, :-(. Pozostałe znaki (np. :P, :*, :D, :-O, :/) występują rzadziej lub zupełnie jednostkowo (np. (X0II) - podwójny hamburger z dodatkami; __m_00_m_ _ strasznie ciekawski człowiek), będąc tym samym dla internautów trudnymi (a nawet niemożliwymi) do rozpoznania kombinacjami znaków interpunkcyjnych i małych/wielkich liter.

Nierzadko w Internecie znaleźć można przykłady naruszania normy gramatycznej czy stylistycznej, charakterystyczne dla potocznej, mówionej odmiany polszczyzny. Wypowiedzi internautów - szczególnie na portalach społecznościowych, forach, czatach czy prowadzone podczas gier - przypominają charakterystyczne dla odmiany mówionej monologi, dialogi czy polilogi: ukazują dominację zdań pojedynczych, o nieskomplikowanej strukturze, nierzadko niepełnych i urwanych. W części z nich trudno jest wyznaczyć granice między poszczególnymi wypowiedzeniami, bowiem internauci świadomie rezygnują $\mathrm{z}$ użycia znaków interpunkcyjnych. W tekstach tworzonych spontanicznie występują liczne partykuły ekspresywne, zaimki, które można uznać za zbędne z punktu widzenia normy stylistycznej języka pisanego czy wyrazy wtrącone. Zdarzają się także anakoluty (błędy składniowe polegające na łączeniu formalnie niezharmonizowanych członów wypowiedzenia). Teksty pod względem logicznym są mało spójne, mają luźną strukturę (zob. przykł. 1-5), pojawiają się zapisane formy oddające przerwy (czy może pauzy), wypełnione przypadkową substancją językową (zob. przykł. 6) czy wyrażeniami o dodatkowej funkcji metakomunikacyjnej (zob. przykł. 7):

- Witam no może z tym generowanym plikiem htaccess się pomyliłem przepraszam nie wiedziałem ze dla wszystkich jest jednakowy a teraz do rzeczy wyjaśnię czemu mi to jest potrzebne a mianowicie miałem prosta stronkę $\mathrm{z}$ podstronami zrobiona $\mathrm{w}$ html i google zaindeksowało mi ją $\mathrm{z}$ podstronami z końcówką .htm a aktualnie tą stronę zamieniłem na stronkę zrobioną w joomli i końcówki są .html i gdy ktoś wyszuka moją stronę to wyskakuje błąd strony bo nie zgadzają się końcówki dlatego też chciałbym aby joomla wyświetlała mi .htm co by rozwiązało sprawę (http://forum.joomla.pl); 
- lechujarek, jakoś dziwnie brzmią Twoje słowa - coś jakbyś z Globa albo EuroLuxa był :) Dla mnie Happy było OK a wątpie żeby kierowcy byli ciepli... Tak czy inaczej odbiegamy od istoty posta i zaczynamy powoli spamować mi chodzi o syf o nazwie EKO i opinie o nim (w drugiej kwestii o to co jest z Happy). (http://forum.gazeta.pl);

- pijani czy bezdomne brudasy albo innego sortu śmierdzace menele jeżdzace nieraz po kilka godzin w tramwaju czy autobusie to od dawna wielki problem. Zastanawiam sie czemu skoro drozeja ceny biletów nasze mpk nie ma czegos w rozdzaju SOK? łajzy czy trole powinni momentalnie wylatywac $z$ tramwaju jeszcze na kopach, i tak nie płaca za bilet a zasmrodzą tak ze godzine jeszcze smierdzi a gdzie mozna spotkac czesto brudasow? np w 64 na wysokosci czechosłowacka-nieraz wrecz po 8 wyczekuja tam na autobus (http://forum.gazeta.pl);

- miałem cośtam kiedyś napisać co u mnie ale nadal mam doła. sprawa z moim dołem jest aż za prosta. gdzieśtam, w nieskrępowanej faktami na mój temat teorii jest też inna teoria, mówiąca, że znalezienie sobie dziewczyny perfekcyjnej dla mnie to kwestia góra miesiąca, zwyczajnie mam to 'coś', pewną swobodę mówienia. a, tak, zapomniałem. przecież proste wyjścia są dla lamerów, przecież jestem gejem. sarkazm off. nikt nie powiedział, że będzie łatwo. ale przez studia planowałem zacząć wpasowywać się w normy a nie jeszcze bardziej od nich odstawać. gdybym mógł to bym się sklonował i przytulił samego siebie aż by mi oczy wyszły na wierzch (http://forum.gazeta.pl);

- niepelnosprytny30 10.04.12, 20:00

Rozmawiałem dziś z koleżanka na rożne tematy. Po jakimś czasie padło zdanie " Wiesz fajny jesteś tylko ten wózek.." No własnie. Tak się teraz zastanawiam i zapraszam do dyskusji. Czy jeśli spodobałby się wam facet a byłby na wózku inwalidzkim ale samodzielny to czy to wszystko przekreśla? Proszę o szczere wypowiedzi a nie słodzenie :D

\section{- Re: Niepełnosprawność - przeszkadza?} marguy 10.04.12, 20:10

$\mathrm{Z}$ mojego doswiadczenie nie przekresla niczego. Mam sasiadow, ona wysoka, zgrabna i ladna dziewczyna, on w wozku, mily, kulturalny i przystojny. Mieszkam tu dwa lata, widuje ich codziennie i wiem, ze zyja zgodnie i bardzo szczesliwie. Wiec wszystko jest mozliwe.

- Re: Niepełnosprawność - przeszkadza? reniatoja 10.04.12, 22:08

A ja znam ładną babkę, która siedzi już 20 lat z brzydalem, grubym, łaciate zęby, który ją bije i pije. $Z$ tego wniosek, że nic niczego nie przekresla. tylko, ze pytanie było inne. Czy gdybyŚ poznała itd. Czy Ty byś. Ja powiem szczerze - wątpliwa sprawa, myślę, ze wózek by mógł wszystko przekreślić. Nie wiem, bo nie byłam w sytuacji, ale nie potrafię wyobrazic sobie, zebym świadomie związała się z osobą na wózku inwalidzkim.

\section{- Re: Niepełnosprawność - przeszkadza?} wez_sie 20.04.12, 15:25

pokaz palcem gdzie w tej historii jest twoje doswiadczenie, plis 
- Re: Niepełnosprawność - przeszkadza? horpyna4 10.04.12, 20:21

Jednym przeszkadza, innym nie. Mnie nie przeszkadzają ułomności fizyczne, za to jestem bardzo wybredna co do cech charakteru.

- Re: Niepełnosprawność - przeszkadza? niewidoczny82 10.04.12, 20:22

podświadomie przeszkadza bo każda dziewczyna chce mieć sprawnego ogiera zawsze gotowego który przyniesie kasę do domu a $\mathrm{z}$ rencinki ciężko wyżyć

- Re: Niepełnosprawność - przeszkadza? reniatoja 10.04.12, 22:10 niewidoczny82 napisał(a): > podświadomie przeszkadza bo każda dziewczyna chce mieć sprawnego ogiera zawsze > gotowego który przyniesie kasę do domu a z rencinki ciężko wyżyć Między innymi. ale chodzi tez o codzienność, pielęgnację, seks, czy zwykłe ograniczenia architektoniczne. Szczery podziw dla siły uczucia ludzi, którzy naprawdę szczerze i bezinteresownie wchodzą w takie związki.

- Re: Niepełnosprawność - przeszkadza? dzidzia.doc 10.04.12, 20:37

Z pewnością nie, wiem choćby z obserwacji - na moich studiach kojarzę z widzenia (inne roczniki) dwóch chłopaków na wózku, każdy z nich ma dziewczynę. A ta koleżanka to średnio taktowna, że tak powiem.

- Re: Niepełnosprawność - przeszkadza? josef_to_ja 28.04.12, 22:15

Wydajesz się bardzo pozytywną osobą

- Re: Niepełnosprawność - przeszkadza? zamysleniee 10.04.12, 20:40

zapewne inaczej odbierana jest niepełnosprawność która stała się podczas związku, a inaczej jak jest ona od początku znajomości o ile taki nastąpi jedne na starcie nie zwiążą się z taką osobą inne nie wytrzymają w takim związku, nie dadzą rady psychicznie lub po prostu fizycznie

- Re: Niepełnosprawność - przeszkadza?

dzidzia.doc 10.04.12, 21:18

Tych dwóch chłopaków na pewno poznało swoje dziewczyny, gdy byli już na wózkach, bo o jednym wiem, że na wózku jest od lat, a drugi ma już nową dziewczynę (gdy w zeszłym roku zaczynałam studia, miał inną).

- Re: Niepełnosprawność - przeszkadza? brak.polskich.liter 10.04.12, 20:43

Nie, nie przekresla. Z przystojnym, bystrym, kontaktowym, ciekawym, stabilnym psychicznie i ogolnie zyciowo pozbieranym facetem na wozku moglabym i umowic sie na randke, i wejsc w blizsza relacje. Wozek sam w sobie nie stanowi problemu. (http://forum.gazeta.p); 
- Widziałem to yyyyyyyyy nie wiem co mam myśleć (http://forum.gazeta.pl);

- no i zastanawiam się tak... mówię ci nie ma z tym łatwo jakby człowiek chciał (www.mpcforum.pl).

Przytoczone cechy składniowe wypowiedzi powstających w sieci są w znacznym stopniu uzasadnione warunkami, w jakich są tworzone i można je porównać do potocznej, spontanicznej wypowiedzi mówionej. Monolog czy rozmowa realizowana $\mathrm{w}$ Internecie mają bowiem często charakter swobodny, zdania nie są z góry przemyślane, rozwijają się stopniowo w trakcie pisania, ponadto są uzupełniane cudzymi wypowiedziami, przez co osoby piszące mają ograniczone możliwości ich uporządkowania i dostosowania do normy składniowej obowiązującej teksty pisane.

Wypowiedzi internautów cechuje także stylistyczne zróżnicowanie słownictwo używane w typie konwersacyjnym, korespondencyjnym, a nawet hipertekstowym jest konkretne, często dosadne i ekspresywne, osadzone najczęściej w rejestrze emocjonalnym. Odnosi się do elementarnych dziedzin zainteresowań przeciętnego człowieka i codziennych spraw: powszechnych zachowań, obyczajów, kontaktów międzyludzkich (prywatnych i służbowych), pracy, wiedzy, moralności, wiary, sztuki itp. Ma tym samym charakter antropocentryczny. Ponadto w języku używanym w sieci, podobnie jak w mówionej odmianie polszczyzny, szerzą się wulgaryzmy:

- dziś jechałem z takim frajerem do pracy. Młody leszcz wsiadał i wysiadał na każdym przystaku opóźniając jazdę.. ech chuj mu w zad (http://forum.gazeta.pl);

- kto to kurwa zrobił że ferie w woj. śląskim nie są tak samo jak w małopolsce ?? idioci siedzą w tym całym ministerstwie edukacji !! (www.tur-info.pl);

- KURWA MAC ZJEBANE TE WASZE FORUM KURWA NIE ODPOWIADACIE TYLKO PIERDOLCIE JAKEIS GLUPOTY GDYBYM MOGL TO BYM JE ROZJEBAL KURWA POSMYLCIE CO WY ODPIERDALACIE ?!!!! TYLKO TEN ZJEBUS COS Z TA PATELNIA WIDOCZNIE NIE ZYWIA GO W CHACIE A ADMIN DAJE KURWA TYLKO BANY I TEMAT ZAMKNIETY BEZ ODPOWIEDZI NA PYTANIE POSTARAJCIE SIE TROCHE (www.mpcforum.pl).

Ponieważ ich używanie na części forów, czatów jest równoznaczne $z$ otrzymaniem ostrzeżenia od administratora (tzw. warn) i blokowaniem konta (tzw. ban), internauci sięgają po eufemizmy:

- o zesz qwa... a ile to "nawiedzonych" mówiło że w tym śledztwie jest coś nie tak? I ile takich o m.c.hrabiów i innych takich twierdziło że nie ma co badać bo wiadomym jest ze winnym katastrofy jest a to pijany Błasik co pilotów przegonił z foteli a to Kaczyński co to ... no właśnie co? (http://forum.gazeta.pl); 
- $\mathrm{ch}^{* * *} \mathrm{w} \mathrm{d}^{* * * *}$ prezesowi kto jest za? (www.bankier.pl/forum);

- Hołdys o Kaczyńskim: To CH... podzielił naród, wprowadził szczucie Polaków na Polaków (www.kciuk.pl);

- ale mi sku\&^\$\%\$dzisiaj uciekł pod łozko , 5 godzin go wyciągałem patykiem, cała rodzina sie zleciała spanikowana , czy aby ten mały szatan na pewno wrócił do akwarium! (www.forumnasze.pl);

- w tym mieście dochodzi już do pewnych absurdów. Niedługo żeby wyciąć drzewo, nieważne jakie (może zagrażać bezpieczeństwu lub być w połowie uschnięte), potrzebne będzie referendum. Naprawdę nie ma o czym pisac? na GW podobnie, afera bo w miejsce budki przy alfie nie posadzili drzewa, nosz qrwa... (http://olsztyn.wm.pl).

Wskazane powyżej cechy polszczyzny występują przede wszystkim w swobodnej, nieoficjalnej komunikacji w sieci, która niewątpliwie dominuje w tym medium. Należy jednak pamiętać, że w Internecie znaleźć można także komunikaty zestandaryzowane, które ze względu na swój charakter, sytuację komunikacyjną tworzone są zgodnie z ogólnie obowiązującą normą wzorcową. Są to najczęściej teksty znajdujące się w oficjalnych e-mailach (służbowych, pisanych do firm/instytucji, jak również do klientów) (zob. przykł. 16-18) czy zamieszczane na witrynach internetowych instytucji, firm, stowarzyszeń (zob. przykł. 19-20):

- Data 2011-2-10

Szanowna/y Pani/Panie

Dziękujemy za wstępną rejestrację w systemie Ekspert Narodowego Centrum Badań i Rozwoju.

W celu wypełnienia formularza prosimy zalogować się na stronie http://www.ncbir.pl/ekspert

Dane konieczne do zalogowania się w systemie:

ID - ********

Hasło - ********

Administrator Bazy Danych

(e-mail otrzymany po zalogowaniu do bazy

Narodowego Centrum Badań i Rozwoju);

- Witaj

Dziękujemy za złożenie zamówienia w Sklepie Orange.

W chwili obecnej trwa weryfikacja podanych przez Ciebie danych. Po poprawnej weryfikacji Twoje zamówienie zostanie przekazane do realizacji.

Szczegóły Twojego zlecenia możesz sprawdzić na stronie orange.pl/status podając numer zamówienia ${ }^{* * * * * * * * * * * * * *}$ oraz kod aktywacyjny: $* * * * * * * * * * * * * *$.

Jeżeli masz pytania lub sugestie dotyczące działania sklepu, prosimy o kontakt: sklep@orange.pl

\section{Pozdrawiamy}

Sklep orange.pl

(e-mail otrzymany po zakupach na stronie WWW Orange); 


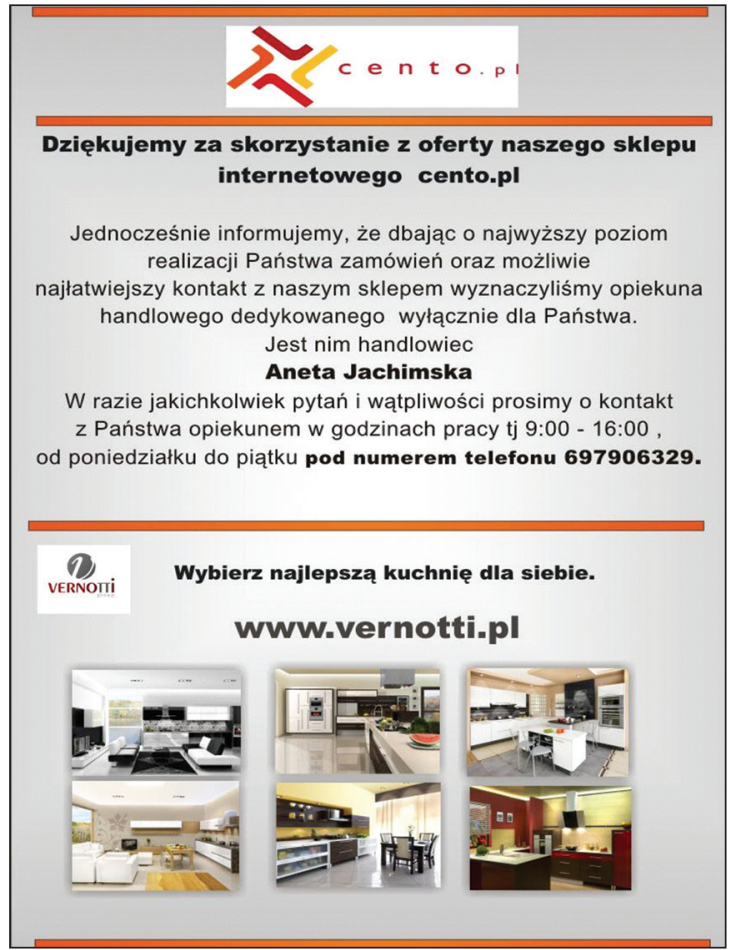

(autoodpowiedź wysłana e-mailem po zakupach w sklepie internetowym);

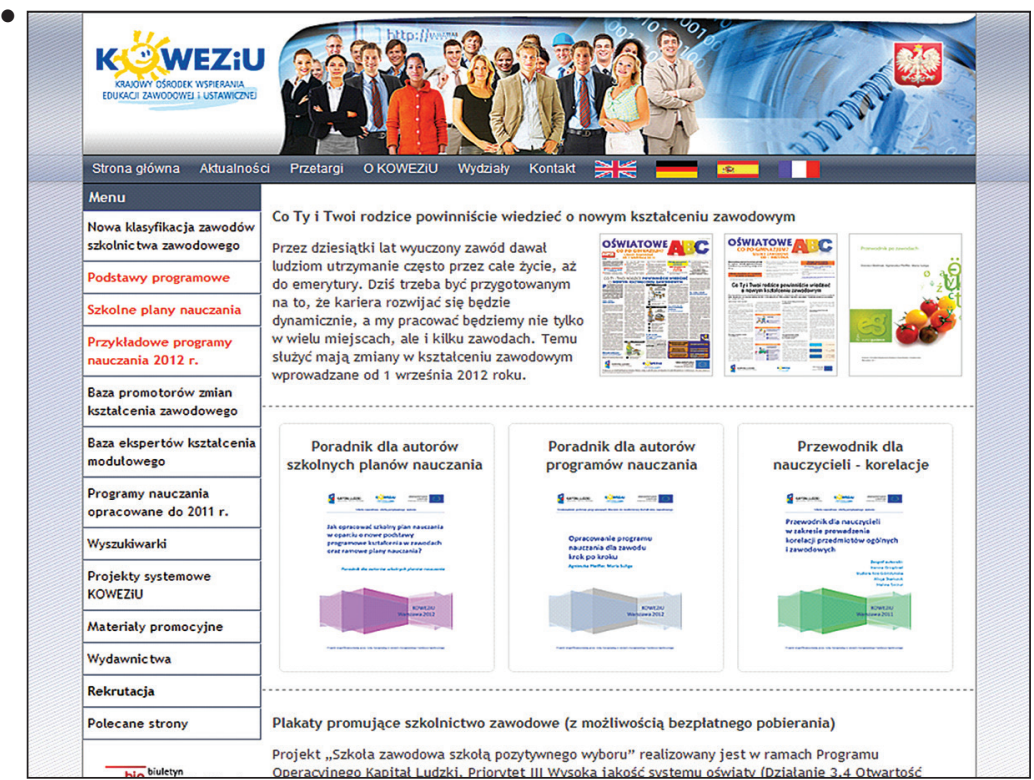

(witryna internetowa Krajowego Ośrodka Wspierania Edukacji Zawodowej i Ustawicznej www.koweziu.edu.pl); 


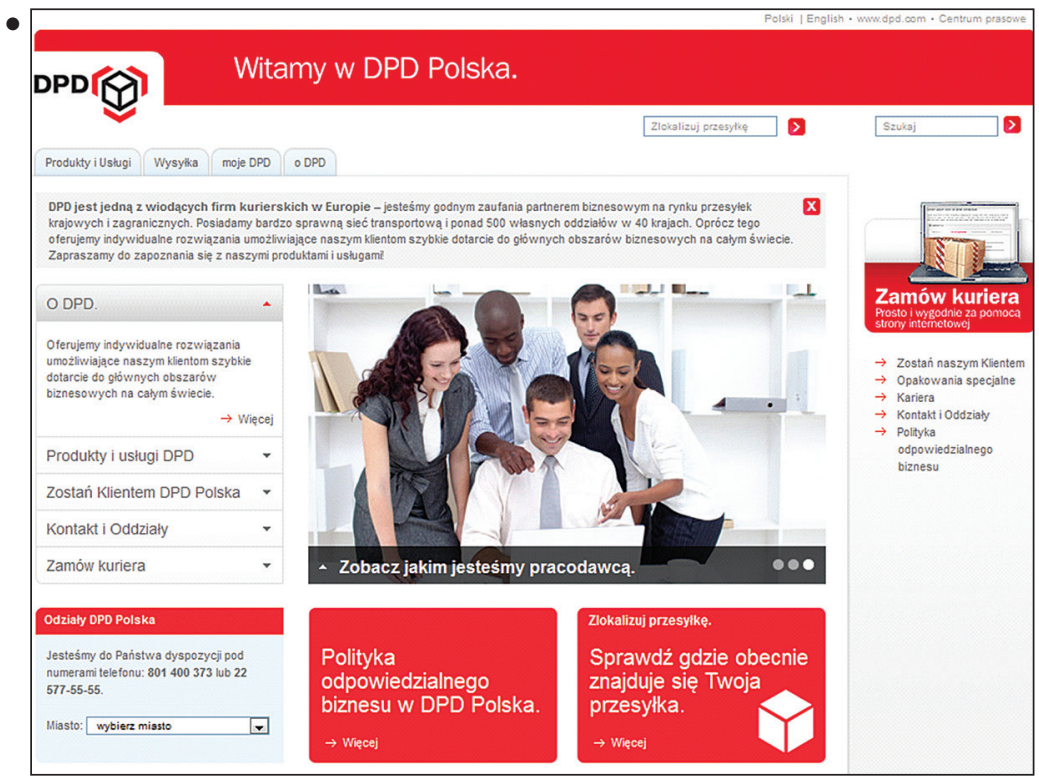

(witryna internetowa firmy kurierskiej DPD www.dpd.com.pl).

Dbałość o kulturę języka na takich witrynach czy w korespondencji oficjalnej jest elementem wizerunku instytucji czy firmy, która przez sieć kontaktuje się $\mathrm{z}$ potencjalnymi odbiorcami/klientami. Rozpoznawalność i podpisywanie się pod e-mailami czy tekstami na stronie WWW imieniem/ nazwiskiem czy w imieniu instytucji/firmy powoduje, że nadawcy czują się odpowiedzialni za jakość komunikacji. Mają także świadomość, że popełnione błędy mogą stać się przyczyną uwag czy drwin internautów, a tym samym nawet zaważyć na wiarygodności firmy.

\section{GrZECZNOŚć W SIECI}

Model grzeczności w polszczyźnie kształtuje się od wielu wieków i na ich przestrzeni ulega przemianom. Społeczność przyjmuje określone wzory konwencjonalnych zachowań etykietalnych, zwyczajowo przyporządkowane sytuacjom pragmatycznym: oficjalnym, półoficjalnym czy zupełnie swobodnym kontaktom. Użytkownicy języka poprzez określone zachowania: gesty, mimikę i - co najważniejsze - przez słowa mają możliwość zachować się zgodnie z wymaganiami sytuacji, w których się znajdują. Celem użycia form, zwrotów grzecznościowych jest bowiem przede wszystkim ułatwianie komunikacji, stworzenie atmosfery, która powinna sprzyjać porozumieniu się 
i wzmocnieniu więzi między rozmówcami. Jeśli użytkownicy języka chcą łamać normy grzecznościowe, to zwykle używają słów czy zwrotów wulgarnych, nieprzyzwoitych, obraźliwych czy agresywnych. Zachowują się w sposób, który narusza godność odbiorcy/odbiorców danego komunikatu i który uniemożliwia skuteczne porozumienie się.

Obecne stosunki ekonomiczne, polityczne i społeczne wywołały szereg zmian w obyczajowości Polaków - normy grzecznościowe, nierozerwalnie związane $z$ normami obyczajowymi, zmieniły się i uległy na przestrzeni ostatniego dwudziestolecia uproszczeniu. Można zaryzykować stwierdzenie, że w społeczeństwie demokratycznym, w którym normą stają się niezłożone relacje między obywatelami a władzą, w swoisty sposób zdemokratyzował się także język. We współczesnej polszczyźnie są oczywiście respektowane główne zasady etykiety, ale jest to specyficzny „układ grzeczności minimalnej, często schematycznej, pozbawionej wielu treści” (np. pozytywnego, życzliwego nastawienia do partnera komunikacji) (Ożóg 2001: 80), niejako ekonomicznej. Zaciera się we współczesnym języku dystans - powszechne jeszcze dwadzieścia lat temu relacje na pan/pani zastępowane są relacjami pośrednimi (np. pani Jadziu, panie Tadeuszu) czy nawet bezpośrednimi (na ty), co wynika m.in. z egalitaryzmu grzecznościowego (niezależnie od wieku każdy człowiek jest równy, jeśli chodzi o prawa i obowiązki względem innych ludzi) oraz zanikania autorytetów. Dążenie do emancypacji kobiet powoduje odchodzenie od zwyczaju mającego w polskiej kulturze wielowiekową tradycję, tj. wyróżniania i traktowania jej w szczególny sposób, zarówno werbalny, jak i niewerbalny (zob. szerzej: Marcjanik 2007: 26-34).

Grzeczność w sieci jest w dużej mierze odbiciem zachowań etykietalnych wyniesionych z codziennej, bezpośredniej komunikacji, przy czym używane formuły grzecznościowe mają postać wyłącznie językową. Ze względu na specyfikę komunikacji elementy parajęzykowe (tempo, intonacja, barwa głosu) oraz niejęzykowe (gest, mimika, proksemika) w tym typie komunikacji nie występują, choć próbuje się je zastąpić środkami graficznymi i tekstowymi. Można także zauważyć, że w Internecie panuje większa swoboda - wspomniane już wcześniej cechy wynikające z pragmalingwistycznego kontekstu i zapośredniczenia komunikacji wpływają na zachowania niespotykane, a nawet niedopuszczalne z punktu widzenia etykiety językowej. Naturalne jest zwracanie się do nieznajomej osoby na „ty” czy naruszanie maksym konwersacyjnych Grice'a (jakości, ilości, odniesienia, sposobu) (zob. Grice 1980: 85-99): 
- Agata....: Z pewnoscia znajdzie sie wielkie grono obroncow tego bandziora! Jestesmy narodem zalkoholizowanych idiotow, ktorzy zawsze znajda wytlumaczenie kazdego zapijaczonego drania. Odnosi sie do zarowno do tych za kierownica zamochodow, jak tez wszystkich grup zawodowych. $Z$ ubolewaniem czytam czeste na forach wypowiedzi tlumaczace nieodpowiedzialne zachowania osob bedacych... pod wplywem. Mozna by powiedziec, ze jest to margines. Nie mniej jednak margines wcale nie taki zawezony. Mamy problem z alkoholizmem na skale alarmujaco duza! "Kultura" piwka po pracy, przed praca i w trakcie pracy stala sie zagrozeniem egzystencji naszego narodu! Polacy szczegolnie powinni unikac napojow "wyskokowych" z prozaicznego nieslychanie powodu. Otoz alkohol wyzwala w naszym cywilizacyjnie nisko stojacym narodzie potrzebe "zawalczenia" z kompleksem nizszosci, a alkohol uruchamia ten mechanizm ze szczegolna latwoscia......

$\sim$ Karolina Kots do Agata....: Ludzie piją przez to, że PO żondzi. odpowiedz

sedoj do Karolina Kots: Jak bym mial kogos takiego w rodzinie jak TY nigdy bym nie byl trzezwy!!!!!

odpowiedz

$\sim$ B. do Karolina Kots: Kpisz sobie! Ale ja nie mam żadnych wątpliwości, że uciemiężony pracownik kolei upił się dlatego, że mu Tusk za mało płaci, przez co kolejarzowi nie wystarcza na godne życie, a jedynie na godne picie. Jeżeli Tusk chce zmazać swoją winę, musi dać 300-procentowe podwyżki wszystkim kolejarzom, a Panom Związkowcom z Kolejarskiej Solidarności musi dać 600\%.

odpowiedz

$\sim$ Egon do $\sim$ B.: Niech da im w naturze-po 0,75 1 na twarz.

odpowiedz

$\sim$ B. do Egon: To jest jakiś pomysł! Ale przynajmniej Panom Związkowcom z Kolejarskiej Solidarności trzeba dać także jakieś pieniądze. Tego wymaga Sprawiedliwość Społeczna.

odpowiedz

mgła do Egon: 0'75 na cały miesiąc?I jak tu się upic?

odpowiedz

$\sim$ mara do Karolina Kots: Dlaczego piszesz takie bzdury?Ludzie pili,piją i pić będą. Ale tylko idioci siadają za kierownicą.Za to powinny być bardzo wysokie kary.Ten "biedny"maszynista-morderca na pewno straci pracę.A potem będzie narzekał,że nie ma co do garnka włożyć,bo w Polsce nie ma pracy. odpowiedz

$\sim$ Karolina Kots do mara: Pewnie wykształcóch z PO. Wy jesteście pijaki i degeneraci co do kościoła nie chodzą.

odpowiedz 
$\sim$ Stary do $\sim$ Agata....: Dlaczego nie napiszecie ze klechy chleja w czasie kazdej mszy.potem po pijaku wsiadaja za kierownice auta?

odpowiedz

dobra rada do Agata....: idź lepiej na spacer i pośpiewaj sobie hymn na euro2012...

(komentarze do artykułu umieszczonego na witrynie WWW http://wiadomosci.onet.pl)

Czy przedstawiona w przykł. 21 rozmowa jest dopuszczalna w bezpośredniej komunikacji? Czy podczas oceny zachowań grzecznościowych można posłużyć się normami etykietalnymi, które na co dzień obowiązują Polaków w zwykłej rozmowie? Językoznawcy (por. Żydek-Bednarczuk 2004; Markowski, Rudnicka 2009; Suska 2012) coraz częściej zwracają uwagę, że normy obowiązujące w języku używanym przez Polaków w bezpośredniej komunikacji nie mogą, a nawet nie powinny być przenoszone bezkrytycznie na język używany w sieci:

Oczywiście warto pisać i mówić głośno o problemach języka w sieci, ale źle pojęta dydaktyka narobi więcej szkody niż pożytku. [...] Tam, gdzie obowiązuje standaryzacja i uniwersalność, warto walczyć o poprawność, ale kreatywności, emocjonalności, fatyczności, ludyczności nie podporządkujemy normom i zasadom zapisanym w Nowym stowniku poprawnej polszczyzny (Żydek-Bednarczuk 2004: 83).

Trudno nie zgodzić się $\mathrm{z}$ takim stwierdzeniem. Komunikowanie się w Internecie - jako miejscu spontanicznego, uwarunkowanego specyficznym kontekstem pragmatycznym porozumiewania - trudno zamknąć w ramach obowiązujących zasad grzecznościowych. Nie można jednak autorytarnie stwierdzić, że w sieci nie obowiązują żadne normy. Społeczność internautów spontanicznie i samodzielnie wypracowała zbiór zasad dotyczących grzeczności w sieci, tj. netykietę (net ang. 'sieć' i etiquette fr. 'formy zachowania się'). „Co istotne, nie jest to zbiór pustych, sztywnych nakazów, a raczej zbiór reguł, który powstał przez lata rozwoju BBS-ów, sieci komputerowych czy wreszcie ogólnie pojętego Internetu" (witryna internetowa netykieta.pl). Warto zwrócić uwagę, że wspomniane zasady nie są w żaden sposób egzekwowane formalnie, jednak każdy z użytkowników sieci może liczyć się z przykrymi konsekwencjami, gdy jego zachowanie będzie odbiegać od tych ogólnie przyjętych norm - wspomniany wcześniej ban, warn czy zgłoszenie niewłaściwych zachowań do abuse, tj. działu u dostawcy usług internetowych, który zajmuje się rozpatrywaniem skarg dotyczących nadużyć.

Netykieta normuje zasady porozumiewania się we wszystkich typach komunikowania występującego w sieci i najczęściej jest prezentowana 
w odniesieniu do określonych gatunków tekstów w niej występujących lub w odniesieniu do określonych narzędzi używanych w internecie. Dalej zostały zestawione najważniejsze jej zasady.

\section{E-maile}

Poczta elektroniczna powinna być odbierana codziennie; gdy wiemy, że będzie się ją odbierać rzadziej, należy to zaznaczyć przy podawaniu adresu.

Należy na bieżąco sprawdzać swój komputer w celu usuwania wirusów, aby nie przesyłać ich innym internautom.

Nie należy spamować, tj. umieszczać reklam, nieistotnych informacji $\mathrm{w}$ wiadomościach pocztowych.

Nie należy rozsyłać łańcuszków szczęścia.

Listy elektroniczne powinny być pisane $\mathrm{w}$ formacie tekstowym, a nie w HTML-u.

W pisowni należy pamiętać o użyciu polskich znaków diakrytycznych.

Wysyłane listy elektroniczne powinny mieć tytuł odzwierciedlający zawartość wiadomości.

Gdy rozsyła się pocztę elektroniczną do grupy osób, należy korzystać z pola „DW” (do wiadomości) czy „UDW” (ukryty do wiadomości), gdyż nie każdy musi sobie życzyć, by jego adres został ujawniony pozostałym odbiorcom listu.

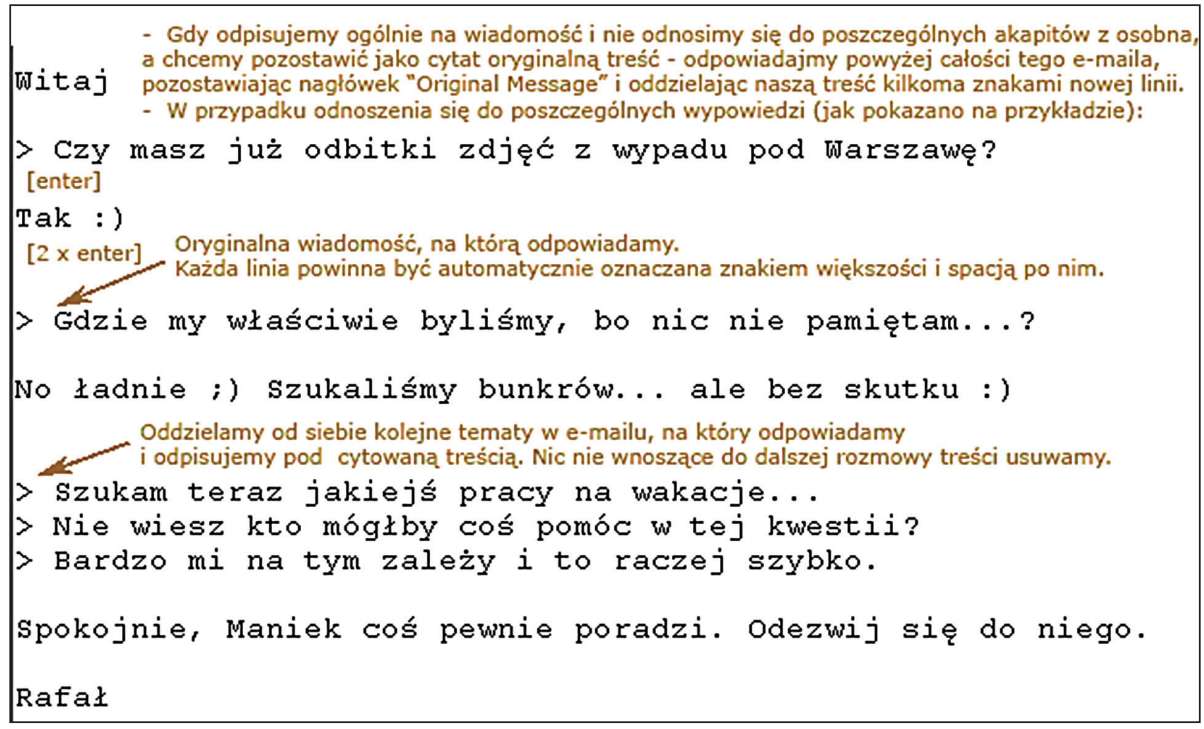

Ilustr. 4. Przykłady cytowania i odpowiadania na e-maile

Źródło: Witryna internetowa netykieta.prv.pl [dostęp: 10.02.2012]. 
Jeśli dołącza się do e-maila kilka/kilkanaście załączników, wskazane jest przed wysłaniem użycie programu do kompresji plików (najczęściej używanymi formatami są: ZIP i RAR).

Stopka w listach elektronicznych nie powinna być dłuższa niż 4 linijki.

Cytowanie:

- nie należy cytować całej wiadomości, chyba że jest to niezbędne,

- gdy cytuje się cudze słowa, należy robić to pod odpowiednim akapitem,

- gdy cytuje się znaczną część otrzymanej wcześniej wiadomości, nie odnosząc się do jej konkretnych fragmentów, należy odpowiadać powyżej cytatu, oddzielając przy tym odpowiedź od oryginalnej wiadomości kilkoma liniami odstępu,

- przed przesłaniem dalej wiadomości należy usunąć nadmiar znaczników cytowania (>), aby w wiadomości było ich jak najmniej.

\section{Strona WWW}

Tworzenie:

- strony WWW należy tworzyć w standardzie ISO-8859-2,

- nie należy przywłaszczać sobie pracy innych osób (grafik, gifów, tekstów itp.),

- nie należy umieszczać na głównej stronie „ciężkich” plików graficznych, bowiem utrudnia to szybkie załadowanie się strony.

Publikacja:

- nie należy tworzyć wielu aliasów strony (czyli domen, np. na prv.pl) - wystarczą dwa adresy, dzięki którym strona będzie łatwo wyszukiwana,

- nie należy umieszczać na stronie bezpośrednich linków do plików (np. mp3) z czyjejś strony, bez wcześniejszej zgody właściciela.

\section{Utrzymanie:}

- stronę WWW należy na bieżąco aktualizować,

- stronę WWW należy na bieżąco kontrolować (księgi gości, fora dyskusyjne itp.),

- jeżeli autor strony rezygnuje z jej prowadzenia, powinien ją usunąć $\mathrm{z}$ sieci lub przekazać innej osobie do prowadzenia.

\section{Blog}

Tworzenie i utrzymanie blogu:

- pisząc blog należy pamiętać o prywatności wszystkich osób, które są w nim opisywane,

- należy usuwać złośliwe, spamerskie komentarze i wpisy do księgi gości. 
Czytanie, uczestnictwo:

- należy szanować uczucia, poglądy innych ludzi i w kulturalny sposób pisać komentarze,

- nie należy trollować, tj. powodować kłótni, prowokować, obrażać, a z drugiej strony nie dawać się prowokować i nie odpowiadać niekulturalnie na cudze zaczepki słowne,

- nie należy floodować, tj. zaśmiecać blogów identycznymi wpisami, np. w komentarzach czy księdze gości,

- nie należy spamować, tj. umieszczać reklam, nieistotnych informacji na cudzych blogach (w komentarzach lub księdze gości).

\section{Komunikatory}

Gdy pisze się po raz pierwszy do innej osoby, należy się przedstawić.

Należy ustawiać status opisowy wtedy, gdy ma się coś ważnego do przekazania.

Nie należy wstawiać do wiadomości galerii emotikonów.

Nie należy rozsyłać łańcuszków szczęścia.

\section{Forum dyskusyjne}

Należy przestrzegać regulaminu grupy dyskusyjnej/forum (znajdują się w nim zazwyczaj szczegółowe zasady etykiety na forum) (por. Wierzbicka 2010: 194).

Nie należy trollować, tj. powodować kłótni, prowokować, obrażać, a $z$ drugiej strony nie dawać się prowokować i nie odpowiadać niekulturalnie na cudze zaczepki słowne.

Nie należy floodować, tj. zaśmiecać forum identycznymi wpisami w obrębie jednego wątku.

Nie należy spamować, tj. umieszczać reklam, nieistotnych informacji na forum.

Należy szanować uczucia, poglądy innych ludzi i w kulturalny sposób pisać posty.

Jeżeli zakłada się na forum nowy wątek do dyskusji, należy nadać mu tytuł odpowiadający treści wpisu.

Nowy temat do dyskusji wymaga założenia nowego wątku na forum.

Należy pisać rzeczowo, tak aby każdy odbiorca mógł zrozumieć komunikat.

Nie należy zadawać pytań, na które już kiedyś na forum została udzielona odpowiedź - należy najpierw przeczytać zamieszczone na forum wątki oraz 
sprawdzić, czy odpowiedź nie znajduje się w tzw. FAQ tej strony (Frequently Asked Questions - najczęściej zadawane pytania).

Nie należy cross-postować, tj. wysyłać tego samego postu do wielu grup dyskusyjnych równocześnie.

Cytowanie:

- nie należy cytować całej wiadomości, chyba że jest to niezbędne,

- gdy cytuje się cudze słowa, należy robić to pod odpowiednim akapitem,

- nie należy używać w stopce na forum obrazków o dużej wielkości (powyżej $100 \mathrm{~KB}$ ) ani nazbyt szerokich czy wysokich (około 150 pikseli) lub umieszczać w niej zbyt wiele linii tekstu.

\section{Czat}

Nie należy trollować, tj. powodować kłótni, prowokować, obrażać, a z drugiej strony nie dawać się prowokować i nie odpowiadać niekulturalnie na cudze zaczepki słowne.

Nie należy floodować, tj. zaśmiecać czatu identycznymi wpisami.

Nie należy spamować, tj. umieszczać reklam, nieistotnych informacji na czacie.

Należy szanować uczucia, poglądy innych ludzi i w kulturalny sposób pisać swoje komunikaty.

Należy pisać rzeczowo, tak aby każdy odbiorca mógł zrozumieć komunikat (zob. szerzej: witryna internetowa netykieta.prv.pl oraz netykieta.pl).

Niezależnie od przytoczonych powyżej zasad netykiety każdy z internautów powinien pamiętać o przestrzeganiu zasad polskiej ortografii oraz specyfice pisowni stosowanej w sieci (wielkich literach, które w Internecie oznaczają krzyk; zwielokrotnianiu liter w zapisie słowa, użyciu asterysków: * czy znaku podkreślenia: _ itp.). Osoby, które nie stosują utrwalonych w sieci sposobów zapisu, zdradzają tym samym brak znajomości zasad rządzących komunikacją internetową i narażają się na krytykę rozmówców, szczególnie w komunikacji korespondencyjnej (na forach i w grupach dyskusyjnych).

Analizując zalecenia netykiety, można zauważyć, że stosuje się ona do trzech podstawowych nakazów: myśl, nie działaj na czyjąś szkodę, nie nadużywaj (por. witryna internetowa netykieta.prv.pl) - uniwersalnych w każdej sytuacji komunikacyjnej w sieci i powiązanych zarówno $\mathrm{z}$ formą, jak i treścią przekazu. Zasady te odbiegają od polskiego modelu grzeczności, gdzie najistotniejsze jest przede wszystkim okazywanie szacunku rozmówcy oraz przejawianie zainteresowania sprawami istotnymi dla rozmówcy (zob. Marcjanik 
1997, 2007; Ożóg 1990), ale równocześnie potwierdzają spostrzeżenie Peisert, iż każda grupa socjalna wypracowuje własne zasady i normy grzeczności, regulujące kontakty międzyludzkie w określonych okolicznościach (1992: 58-59). Warto zwrócić uwagę, że występujące różnice mogą wynikać $\mathrm{w}$ dużej mierze $\mathrm{z}$ formy kontaktu oraz braku komunikatów niewerbalnych. Próby zastępowania subkodu supersegmentalnego (akcent, intonacja, natężenie głosu, melodia, tempo) charakterystyczną dla Internetu pisownią, czy też odtworzony w niewielkim stopniu za pomocą pisma subkod paraleksykalny nie dają internautom zbyt szerokiej palety środków do zastosowania podczas komunikacji zapisanej. Również brak kodu kinetycznego (mimiki, ruchów głowy i całego ciała, gestów) oraz proksemiki (informacji o dystansie intymnym, osobistym, społecznym i publicznym) zubaża przekaz internetowy. Tekst i słowo zapisane stają się więc jedynym środkiem wyrazu grzeczności w sieci, dlatego nawet neutralne komunikaty bywają odczytywane jako napastliwe. Gdy odbiorca zinterpretuje czyjąś wypowiedź jako agresywną i sam ostro odpisze, najpierw rodzi się frustracja, prowadząc do eskalacji agresji, która w kontakcie bezpośrednim nie miałaby w ogóle miejsca lub zostałaby niezwykle szybko zażegnana (zob. szerzej: Wallace 2004: 150, 155-156). Agresja werbalna rodzi się zwykle z przekonania, że bycie anonimowym w sieci daje pełną swobodę zachowań wobec interlokutorów, a jeśli doda się do tego także zwiększone poczucie ego internautów z racji samotnego przebywania przed ekranem komputera, to pojawiają się zachowania, które w kontakcie twarzą w twarz nie zaistniałyby wcale. Można w takich sytuacjach mówić o świadomym odrzucaniu aprobowanych społecznie zachowań grzecznościowych i łamaniu norm. Warto zaznaczyć, że takie napaści słowne mają miejsce jedynie w kontaktach nieoficjalnych, symetrycznych - głównie na czatach, forach dyskusyjnych czy poprzez komunikatory, gdy rozmówcy kryją się pod nickami (pseudonimami tworzonymi na użytek komunikacji w Internecie).

Wspomniane łamanie zasad netykiety czy nieużywanie form grzecznościowych występuje także $\mathrm{w}$ tekstach oficjalnych tworzonych w sieci i przekazywanych za jej pośrednictwem. To zjawisko ma jednak zupełnie inne podłoże, niż w przypadku kontaktów nieoficjalnych (tj. towarzyskich, prywatnych). Użytkownicy Internetu, przyzwyczajeni do nieformalnych rozmów za pośrednictwem komputera, tracą często dystans wynikający z niesymetrycznych kontaktów międzyludzkich (np. instytucja - petent, szef - podwładny, student - wykładowca). Takie zachowania wynikają z jednej strony $z$,awansu potoczności”, gdzie zachowania prywatne przenoszone są na komunikowanie publiczne, $\mathrm{z}$ drugiej zaś wskazują na czerpanie 
z wzorców obcych, przede wszystkim amerykańskich, w których naturalnym zjawiskiem jest mówienie na „ty” i swobodne zachowanie wobec osoby, z którą się rozmawia (zob. netografia: Skudrzyk: 8). Dodatkowym problemem wydaje się brak znajomości wzorców gatunków użytkowych takich tekstów, jak prośba, przeprosiny, list, co prowadzi do złamania nie tylko zasad grzecznościowych, lecz także konwersacyjnych w komunikacji przez Internet. Ilustracją takich sytuacji, wskazującą na swobodne zachowania językowe realizowane przez studentów w korespondencji z nauczycielami akademickimi, są przykł. 22-28 (dane adresatów e-maili zostały ukryte) - szerzej zob. Wierzbicka 2008: 431-443.

Biorąc pod uwagę sytuację komunikacyjną (oficjalną), różną hierarchię rozmówców, należy stwierdzić, że przytoczone nagłówki (Witam!, Witam serdecznie), zwroty adresatywne (Pani Agnieszko) lub zupełny brak zwrotów otwierających czy zamykających korespondencję elektroniczną - prowadzą do odwrócenia relacji nadawczo-odbiorczej. Student jawi się w rozmowie co najmniej jako równorzędny partner, a czasami nawet jako osoba nadrzędna względem nauczyciela akademickiego. Formy, zwroty grzecznościowe używane przez studentów balansują na granicy oficjalności i nieoficjalności. Tworzą się formy komunikacji półoficjalnej - z charakterystycznym dla niej skróceniem dystansu i bardzo wyraźnym wyrażaniem emocji - wypierając typowe dla środowiska akademickiego zachowania językowe. Do języka studentów przenoszone są niektóre cechy języka nieoficjalnego, funkcjonującego powszechnie w sieci: spontaniczność, kolokwialność, sytuacyjność, użycie emotikonów, brak dbałości o formę wypowiedzi itd. Można oczywiście zastanawiać się, na ile przytoczone przykłady obrazują brak znajomości wzorców gatunkowych obowiązujących w komunikacji oficjalnej (tj. list, prośba, podziękowanie, przeprosiny), czy wynikają z rozchwiania wzorca gatunkowego, jakim jest e-mail (połączenie listu tradycyjnego i rozmowy) (por. Marcjanik 2007: 70-71), ważne jest jednak, by nawet w takich wypowiedziach zachowywać stosowny do sytuacji umiar i dystans, co umożliwia wzajemne poszanowanie uczestników komunikacji (choćby poprzez użycie właściwych form adresatywnych, tj. Szanowna Pani Magister/Doktor/Profesor czy Pani Magister/Doktor/Profesor, czy poprzez stosowanie w treści listu form nienacechowanych emocjonalnie). Również właściwie i pełnie podane informacje pozwalają na skuteczne i szybkie porozumienie się (zob. przykł. 29). 


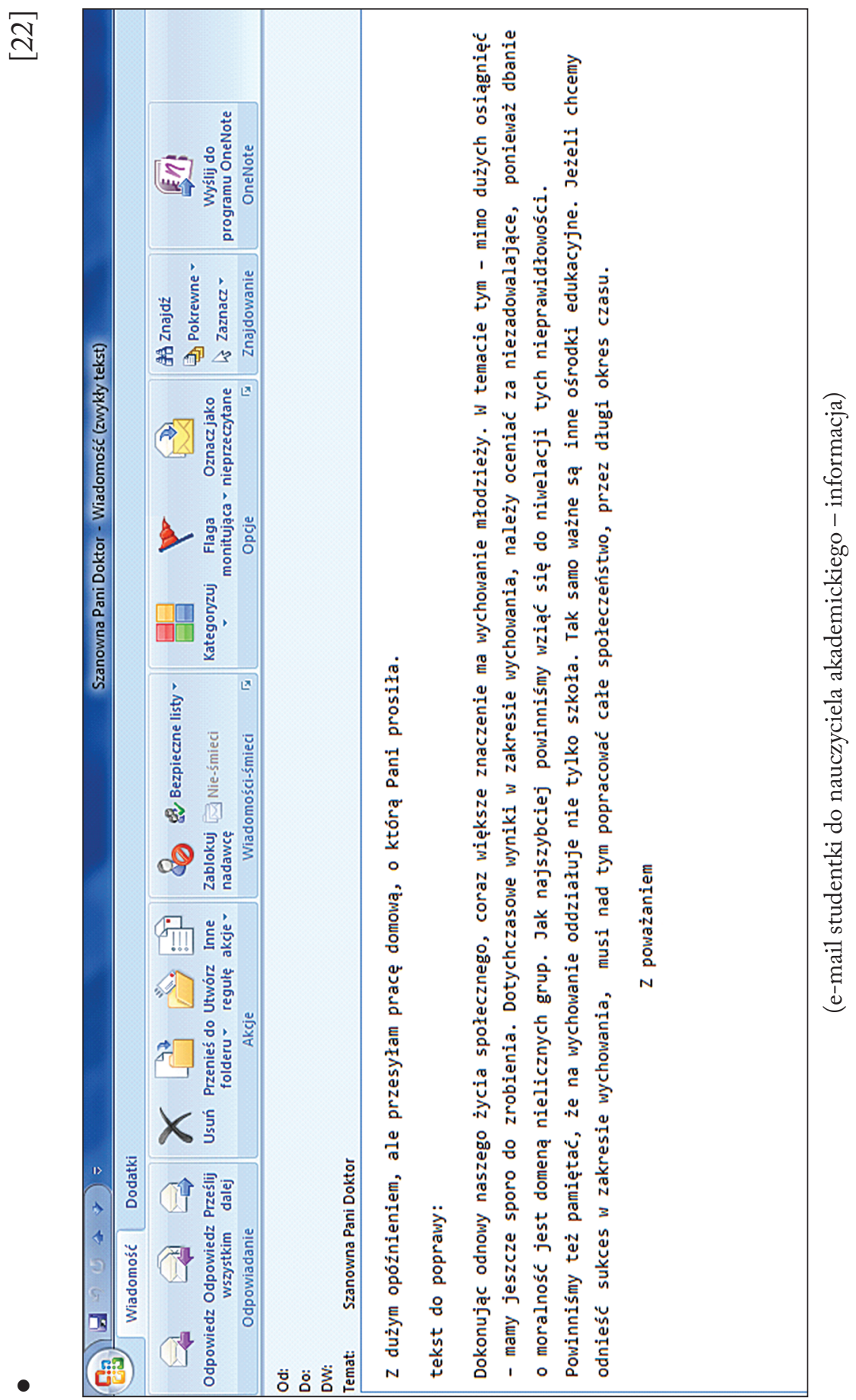




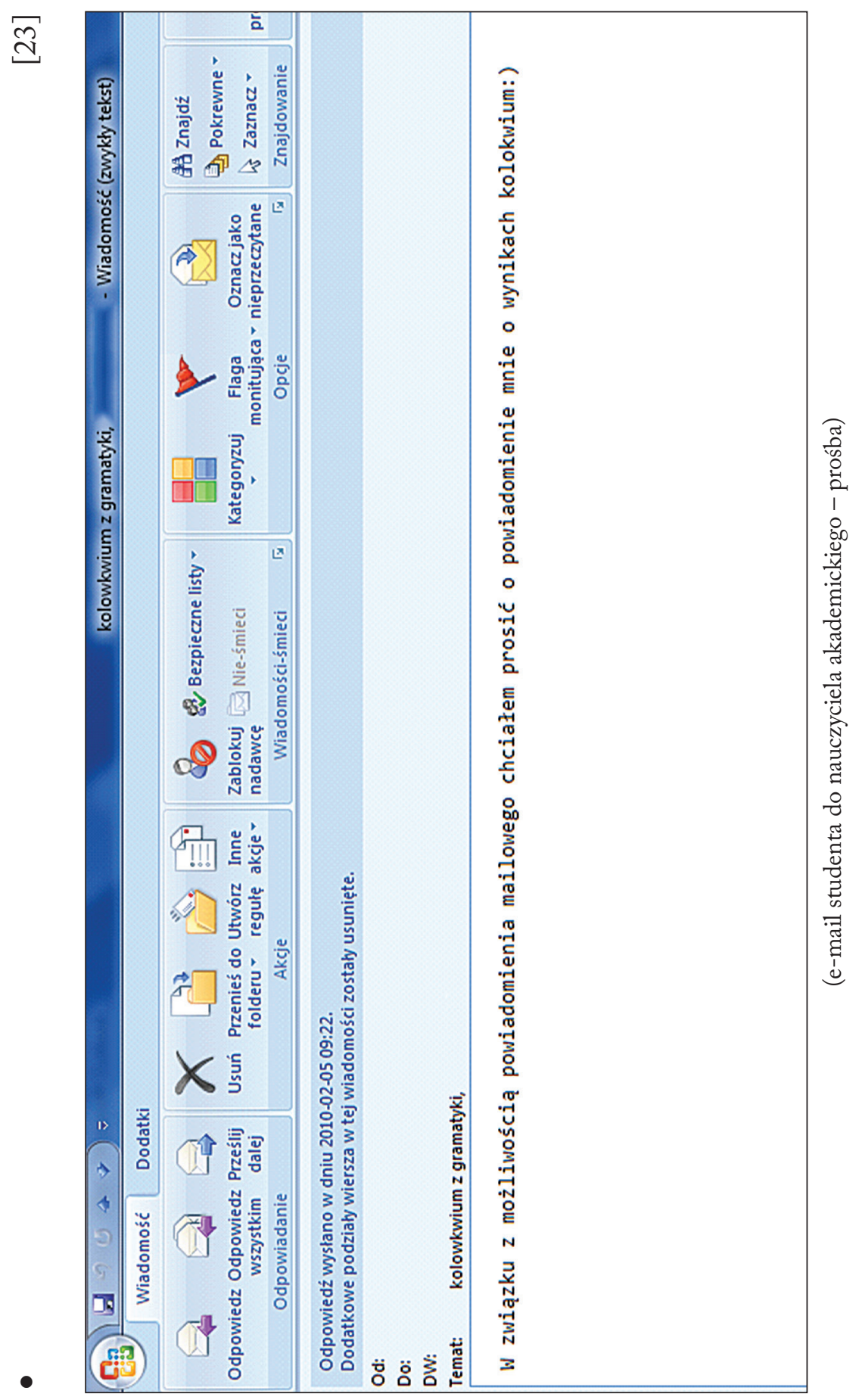




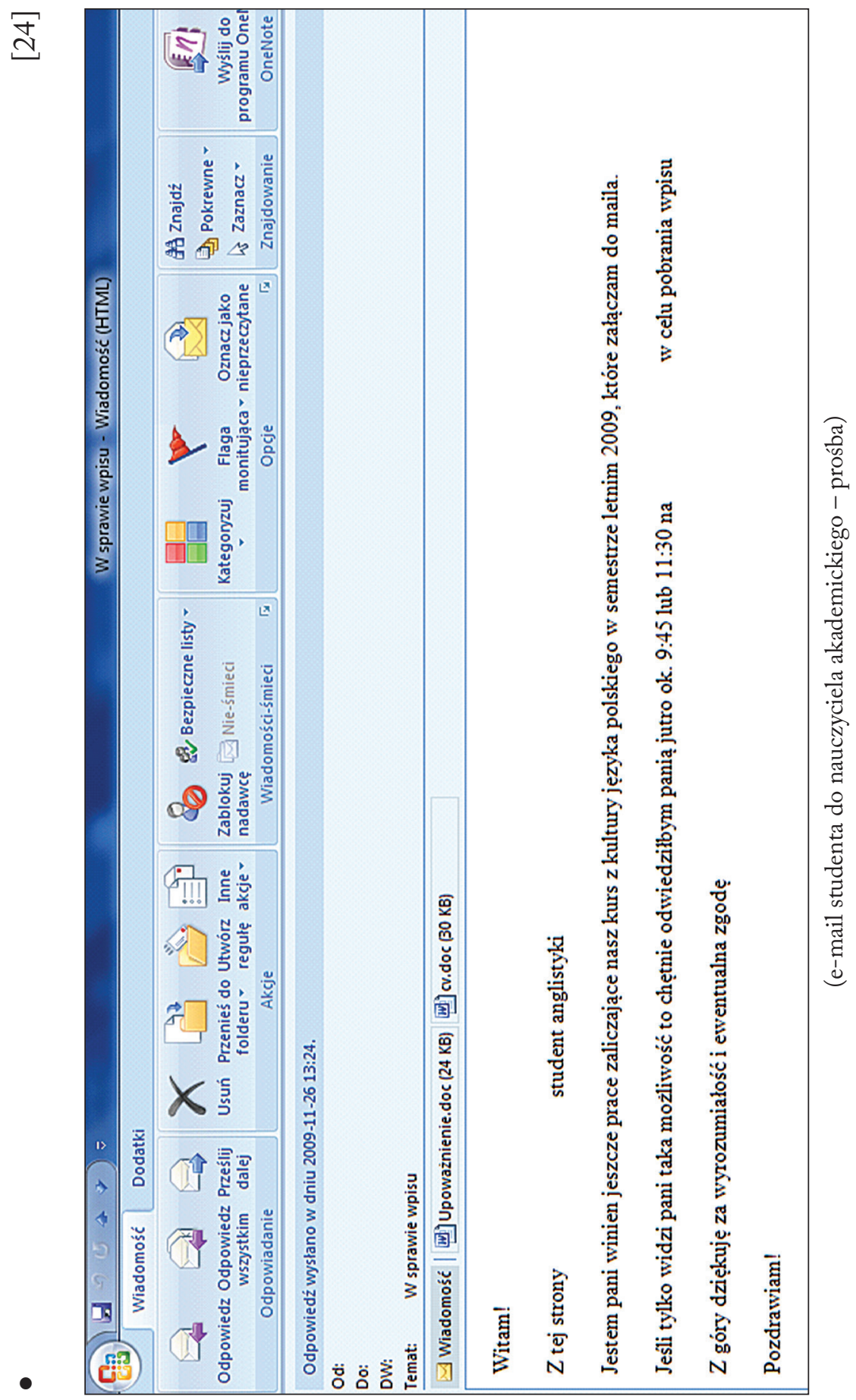




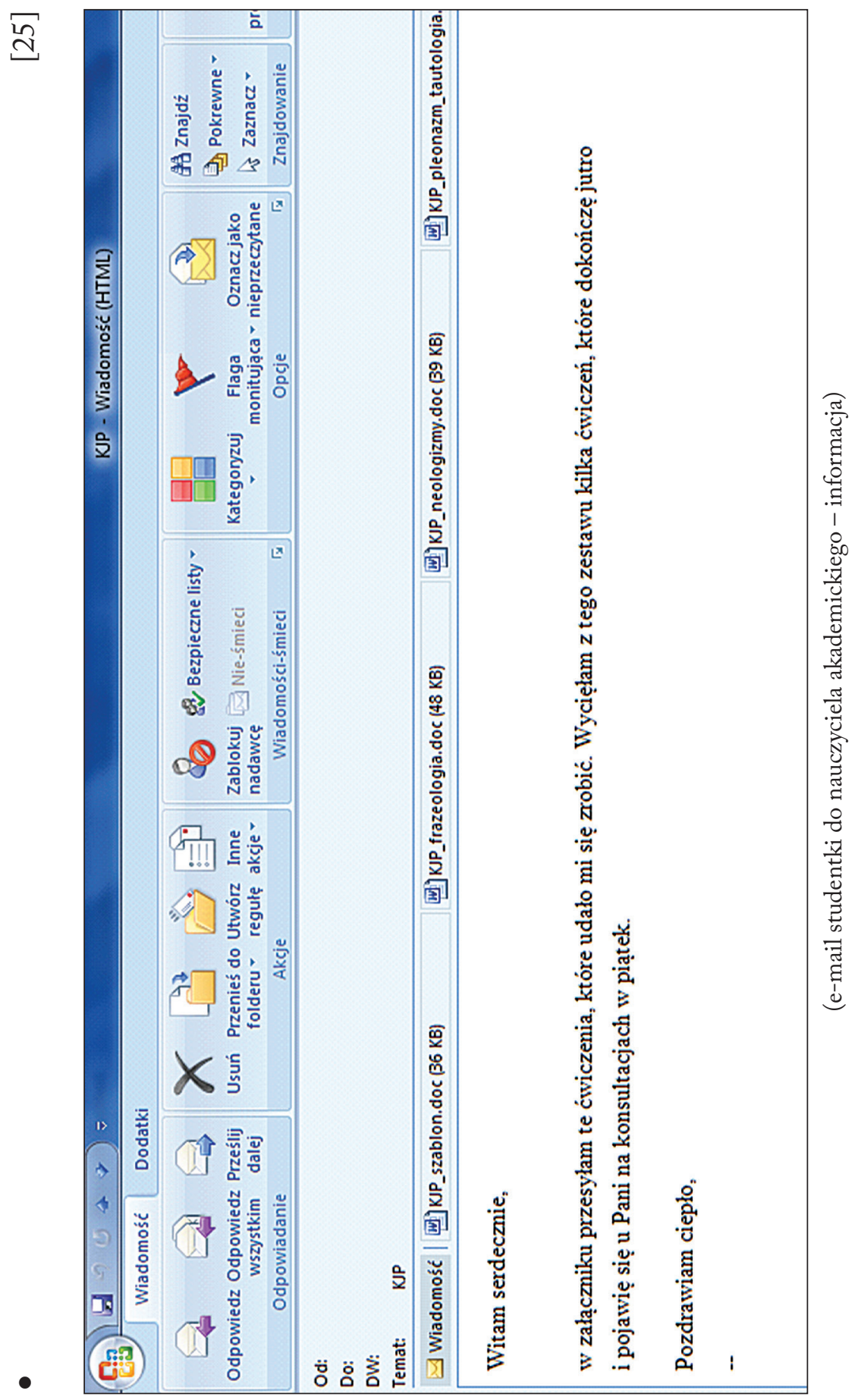




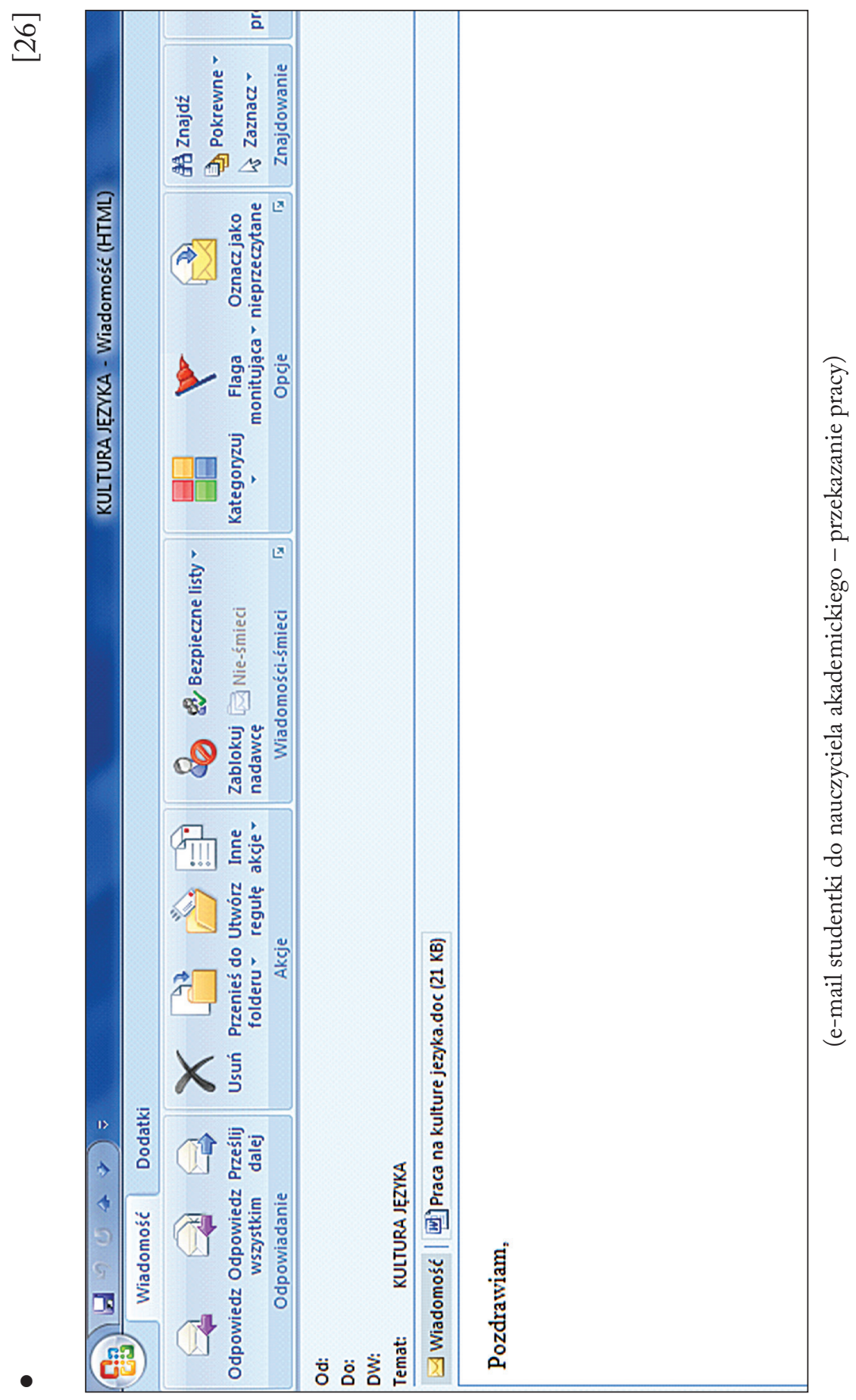




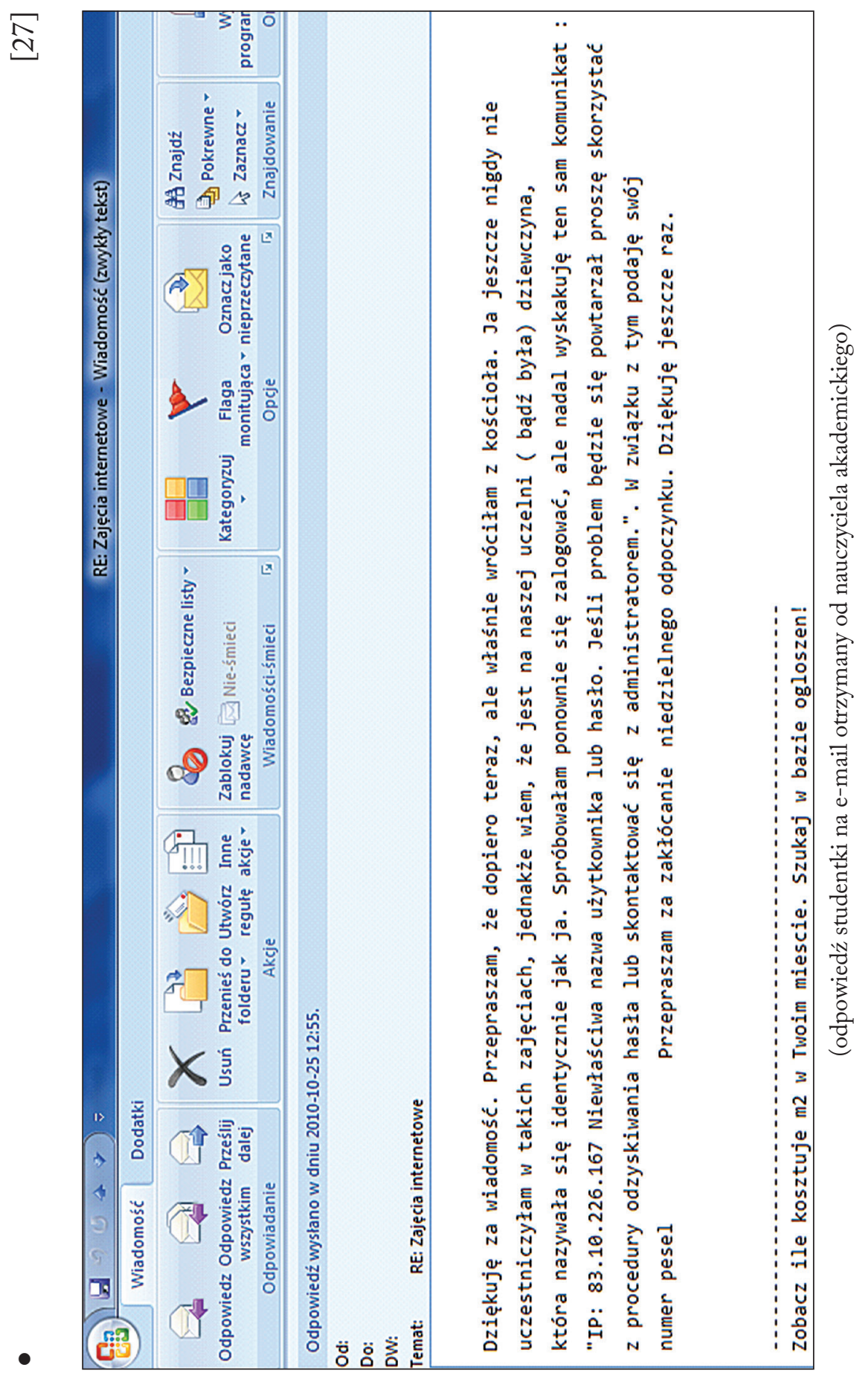




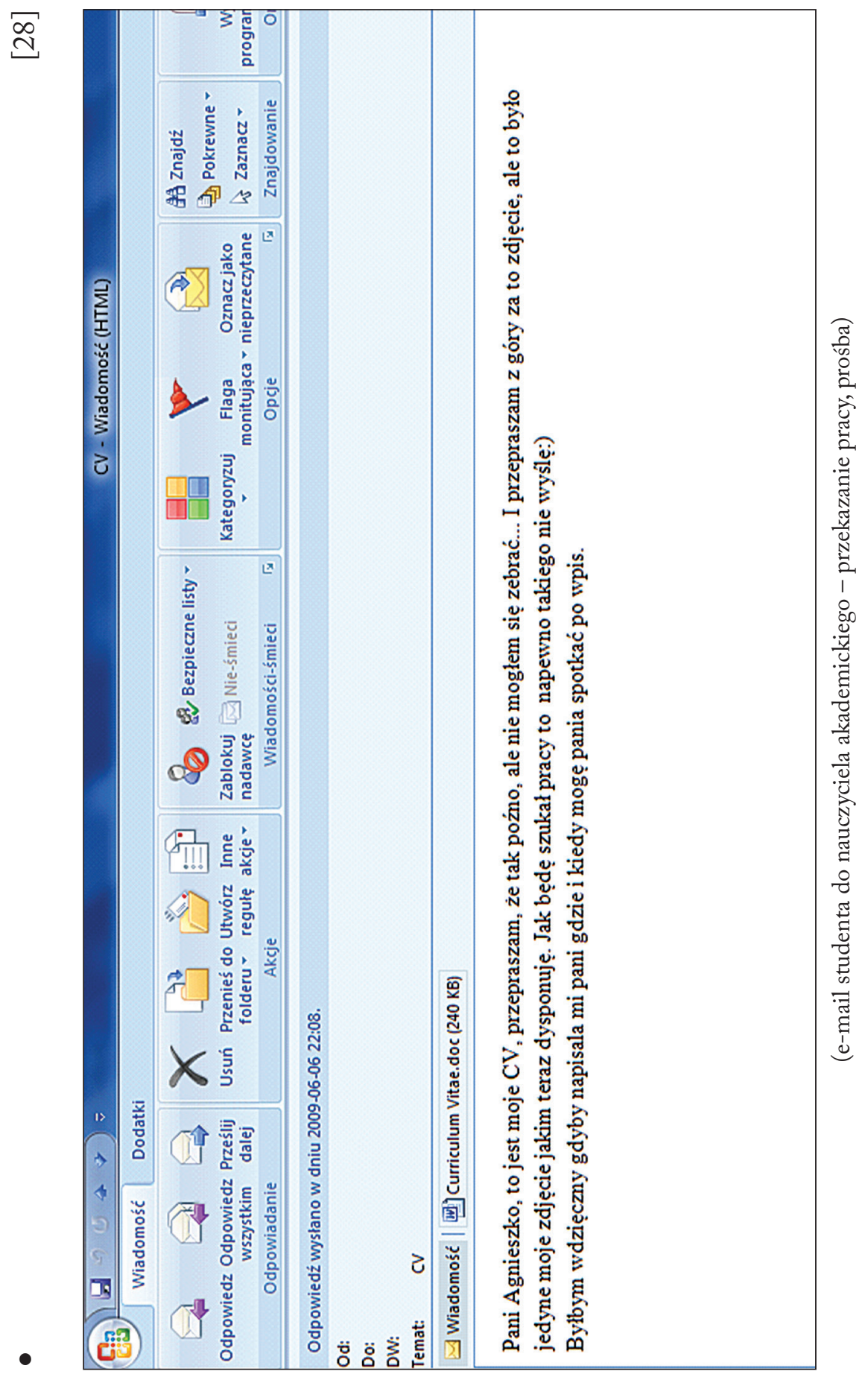




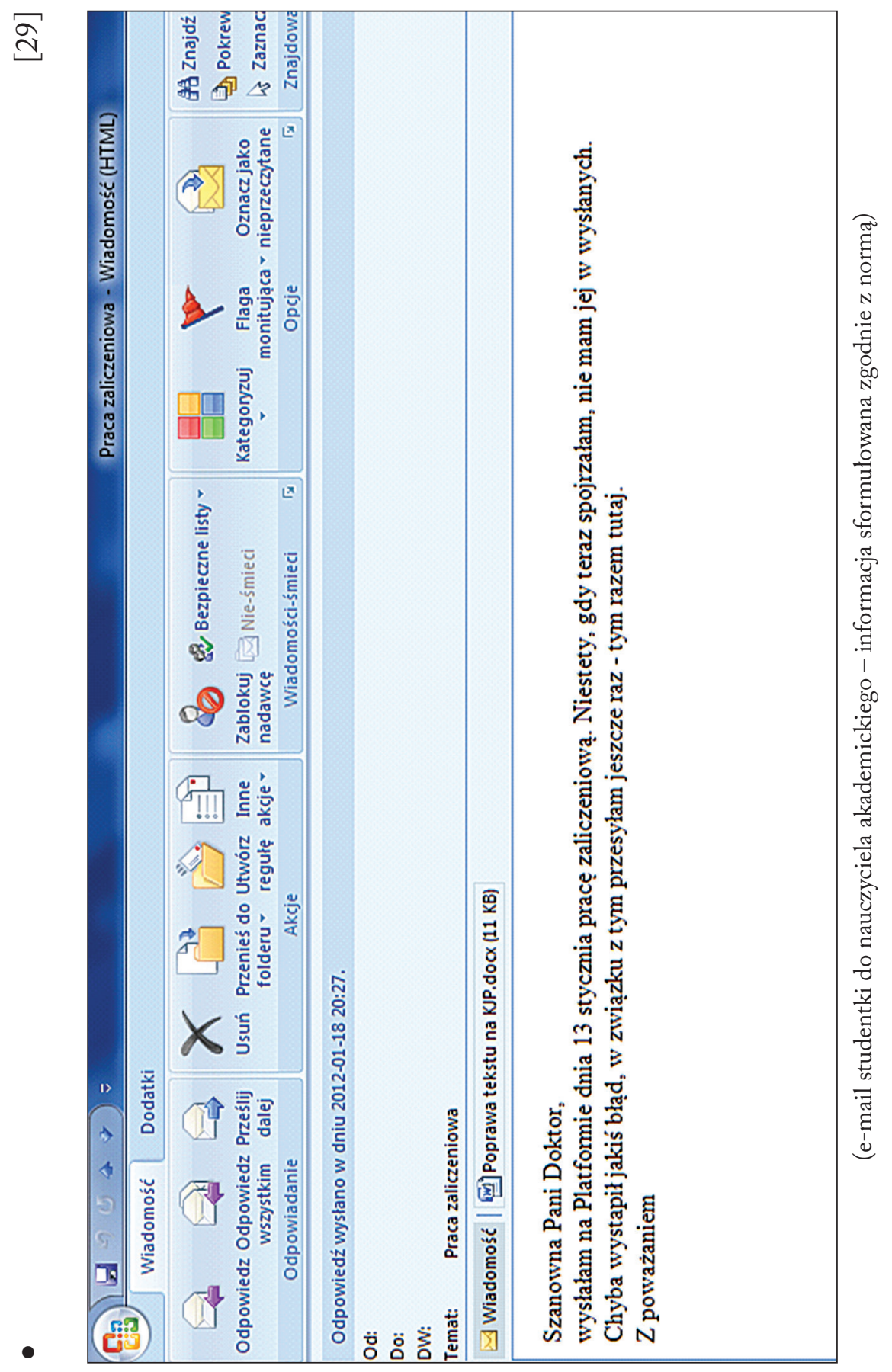


Wskazaną nieporadność w konstruowaniu wypowiedzi oficjalnych, zapisanych, można dostrzec także w innych sytuacjach - w korespondencji zwierzchnika $\mathrm{z}$ podwładnym, urzędu $\mathrm{z}$ petentem, firmy $\mathrm{z}$ klientem. I tu również da się zaobserwować nieumiejętność użycia zwrotów adresatywnych, np. powszechne jest rozpoczynanie oficjalnych listów elektronicznych od słowa Witam połączonego czasami z formą Paniq/Pana (Witam Pana/Paniq /Państwa). Mało który użytkownik sieci uświadamia sobie, iż forma Witam sygnalizuje relację nierównorzędną, bowiem jest to 1. osoba liczby pojedynczej: ja witam (zob. Marcjanik 2007: 73), demonstrującą indywidualizm, a więc nieadekwatną do oficjalnej komunikacji. Niezręczne i niestosowne w takich sytuacjach jest także używanie form półoficjalnych, np. Pani Matgosiu, Panie Grzegorzu, czy nawet na ty, np. Agnieszko! Piotr! (przykłady te pochodzą z korespondencji elektronicznej prowadzonej z klientami przez banki, firmy). Formuły zamykające oficjalne e-maile bywają równie niefortunne: Pozdrawiam, Pozdrawiam goraco, Serdeczności, Przesytam serdeczne pozdrowienia itp. Wskazują one również na skrócony dystans i brak powściągliwości w kontakcie $\mathrm{z}$ rozmówcą.

\section{Podsumowanie}

Komunikacja za pośrednictwem sieci jest niejednolita - w tej przestrzeni obok braku dbałości i często świadomego łamania reguł przez poszczególnych użytkowników można znaleźć strony osób prywatnych czy instytucji stosujących się do ogólnych norm i zasad języka, a tym samym propagujących sprawność językową i kulturę języka. Różnorodność stosowanych w Internecie stylów, wielość sytuacji komunikacyjnych nie pozwala na łatwy opis używanego tam języka. Tym bardziej, że medium pośredniczące w komunikacji zmienia percepcję docierających do odbiorców komunikatów. Słowo zapisane, pozbawione pozajęzykowego tła, charakterystycznego dla bezpośredniej komunikacji, często traci swój neutralny charakter, a jego odczytanie możliwe jest na wiele sposobów. Te czynniki wprowadzają zakłócenia i nie zawsze właściwe dekodowanie komunikatów przez uczestników aktu komunikacji $\mathrm{w}$ sieci.

Obserwując zachowania komunikacyjne i grzecznościowe Polaków w Internecie, można pokusić się o stwierdzenie, że w tej przestrzeni porozumienie bywa czasami realizowane zgodnie $z$ maksymami konwersacyjnymi Grice’a i ogólnie obowiązującą normą, ale - o wiele częściej - wbrew tym regułom. Komunikacja w sieci nadal określana jest jako nowa, nie w pełni ukształtowana, będąca pod ogromnym wpływem dynamicznie zmieniającej się polszczyzny mówionej. Od ponad dwudziestu lat, na niespotykaną dotąd 
skalę w historii języka polskiego, internauci używają do porozumiewania się wyłącznie pisma - ta sytuacja musi spowodować zmiany w zachowaniach językowych. Pojawiają się nowe sytuacje i zachowania, nieznane $z$ bezpośredniej komunikacji, nowe narzędzia umożliwiające kontakt, a to wymaga powolnego wykształcania innych niż dotychczas form porozumiewania się, nowych gatunków tekstów, nowych zachowań grzecznościowych, które z czasem będą miały szansę na utrwalenie się w ludzkiej świadomości i zachowaniach. Nie powinno się oceniać takich zmian wyłącznie negatywnie, jedynie z perspektywy norm obowiązujących w polszczyźnie ogólnej, ale nie można też zapomnieć, że Internet jest przestrzenią, w której dochodzi do komunikacji oficjalnej i tu ogólnie ustanowione w polszczyźnie zasady językowe i grzecznościowe powinny być przestrzegane.

Internet tworzy nowy, wirtualny wymiar rzeczywistości, którego każdy człowiek bezpośrednio doświadcza. Ogromy potencjał sieci pozwala na przedłużanie rzeczywistych kontaktów międzyludzkich, a tym samym stwarza niezwykle szeroką perspektywę komunikacyjną.

\section{Bibliografia}

Chaciński B. (2003), Wypasiony stownik najmtodszej polszczyzny, Kraków.

Data K. (2009), Wptyw komunikacji sieciowej na wspótczesna polszczyznę, [w:] D. Ulicka (red.), Tekst (w) sieci. Tekst. Jezzyk. Gatunki, Warszawa, s. 131-138.

Gajda S. (2000), Media - stylowy tygiel wspótczesnej polszczyzny, [w:] J. Bralczyk, K. Mosiołek-Kłosińska (red.), Jezzyk w mediach masowych, Warszawa, s. 19-27.

Godzic W. (2000), Język w Internecie: Czy piszemy to, co myślimy?, [w:] J. Bralczyk, K. Mosiołek-Kłosińska (red.), Język w mediach masowych, Warszawa, s. 176-185.

Grice P. (1980), Logika i konwersacja, „Przegląd Humanistyczny”, nr 7, s. 85-99.

Gruszczyński W. (2001), Czy normy językowe obowiazuja w Internecie?, [w:] J. Bralczyk, K. Mosiołek-Kłosińska (red.), Zmiany w publicznych zwyczajach językowych, Warszawa, s. 183-190.

Grzenia J. (2006), Komunikacja jezykowa w Internecie, Warszawa.

Kisiel P. (1991), Etykieta jezzykowa a wzory kultury, [w:] J. Anusiewicz, M. Marcjanik (red.), Polska etykieta językowa, „Język a Kultura”, t. 6, [Wrocław], s. 9-14; www.lingwistyka.uni. wroc.pl/jk.

Labocha J. (2004), Tekst pisany - tekst zapisany, „Biuletyn Polskiego Towarzystwa Językoznawczego", t. LX, s. 5-10.

Marcjanik M. (1993), Etykieta językowa, [w:] Encyklopedia kultury polskiej XX wieku, t. 2: Wspótczesny jezzyk polski, red. J. Bartmiński, Wrocław, s. 271-281.

Marcjanik M. (1997), Polska grzeczność jezzykowa, Kielce.

Marcjanik M. (2007), Grzecznośc w komunikacji językowej, Warszawa.

Markowski A. (2011), Jezzykoznawstwo normatywne dziś i jutro: stan, zadania, szanse, zagrożenia; www.rjp.pan.p1/index.php.

Markowski A., Rudnicka E. (2009), Dwugtos w sprawie kultury jezzyka dzis, [w:] K. Ożóg (red.), Jezzyk żyje. Rzecz o wspótczesnej polszczyźnie, Rzeszów. 
Miller S. (2003), E-mailowy savoir-vivre, Poznań.

Ożóg K. (1990), Zwroty grzecznościowe wspótczesnej polszczyzny mówionej, Kraków.

Ożóg K. (2001), Uwagi o wspótczesnej grzeczności językowej, [w:] K. Ożóg, Polszczyzna przetomu XX i XXI wieku. Wybrane zagadnienia, Rzeszów, s. 73-84.

Peisert M. (1992), Etykieta jezzykowa jako przejaw edukacji spotecznej i kulturowej, [w:] J. Anusiewicz, M. Marcjanik (red.), Polska etykieta językowa, „Język a Kultura”, t. 6, [Wrocław], s. 57; www.lingwistyka.uni.wroc.pl/jk.

Rocławski B. (2009), Postá́ graficzna i ortograficzna polskich tekstów w sieciach, [w:] D. Ulicka (red.), Tekst (w) sieci. Tekst. Jezzyk. Gatunki, Warszawa, s. 101-120.

Steciąg M., Bugajski M. (red.) (2009), Norma a komunikacja, Wrocław.

Suska D. (2012), O kulturze języka w internecie dzis-rekonesans badawczy, [w:] K. Michalewski (red.), Język nowych mediów, Łódź, s. 99-109.

Wallace P. (2004), Psychologia Internetu, Poznań.

Wierzbicka A. (2008), Jezzyk i zachowania sieciowej spoteczności akademickiej, [w:] M. Sokołowski (red.), Media i spoteczeństwo. Nowe strategie komunikacyjne, Toruń, s. 431-443.

Wierzbicka A. (2010), Regulamin internetowego forum dyskusyjnego-próba charakterystyki gatunku, [w:] K. Michalewski (red.), Jezzyk w prawie, administracji i gospodarce, Łódź, s. 187-198.

Zalewska-Greloch E. (2008), Polszczyzna internautów - poprawna czy... „wygodna”?, [w:] J. Podracki, E. Wolańska (red.), Język w mediach elektronicznych, Warszawa, s. 155-172.

Żydek-Bednarczuk (2004), Kultura języka w Internecie, [w:] M. Sokołowski (red.), Oblicza Internetu, Elbląg, s. 71-84.

\section{Netografia}

[dostęp: 10.05.2012]

Bugajski M., Etyka, etykieta, kultura jezyka; www.uz.zgora.pl/ mbugajsk/wp-content/plugins/ downloads-manager/upload/Etyka1.pdf.

Cudowska A., Medialna rzeczywistośc jako środowisko życia wspótczesnego człowieka. Kontekst etyczny; http://winntbg.bg.agh.edu.pl/skrypty2/0096/417-426.pdf.

Grybosiowa A., O wspótczesnym stosunku do normy jezzykowej; www.poradniajezykowa.us.edu.pl/ artykuly/AG_o_wspolczesnym.pdf.

Kulturowy savoir-vivre. Przewodnik dla osób o dobrych intencjach; www.bezuprzedzen.org/doc/ kulturowy_savoirvivre.pdf.

Łuc I., „Bezpieczeństwo” kultury języka. Etykieta językowa w szkole i poza szkota - pomiędzy dialogiem a betkotem; http://seminarium.21.edu.pl/ks/4/1.04.\%20LUC\%20IZABELA.pdf.

Poradnia Językowa PWN, Jak zaczą́ majl, http://poradnia.pwn.pl/lista.php?id=11110.

Skudrzyk A., Norma grzecznościowych zachowań językowych (etykieta językowa, savoir-vivre, bon ton, dobre wychowanie, grzecznośc językowa); http://sjikp.us.edu.pl/pliki/ksiazki/aldona_skudrzyk.pdf.

Wideoblog Jerzego Bralczyka, Etykieta językowa w Internecie; www.mojageneracja.pl/4142/ blog/3193568314ae99af6bcf12/0.

Witryna internetowa netykieta.pl, http://netykieta.pl/wprowadzenie.

Witryna internetowa netykieta.prv.pl, http://netykieta.prv.pl. 